doi:10.29285/actapinteriana.2020.6.89

\title{
Levelek Rómából, 1966: \\ Adalékok a Ferences Rend zsinati megújulásának történetéhez
}

\author{
Várnai Jakab OFM \\ Sapientia Szerzetesi Hittudományi Főiskola, 1052 Budapest, Piarista köz 1. \\ varnai.jakab@sapientia.hu
}

Várnai J. (2020): Levelek Rómából, 1966: Adalékok a Ferences Rend zsinati megújulásának történetéhez. Letters from Rome: Some Historical Sources on the Post-Conciliar Renewal of the Franciscan Order. Acta Pintériana, 6: 89-117.

\begin{abstract}
The article is basically the Hungarian translation of the 15 letters written by Lothar Hardick OFM to his Minister provincial Dietmar Westemeyer between 13 April and 22 June, 1966, from the General Curia of the Franciscan Order in Rome. Hardick was a member of the international commission of the Order working on preparing the draft of the new General Constitutions after the 2nd Vatican Council, on the basis of a dialogue with the friars in each Province. The letters give an insight into the working method of the commission and into the principles that guided the renewal of the Order in the years immediately following the Council.
\end{abstract}

2011-ben A Regula a 20. században címmel írtam egy tanulmányt egy kötetben, amely a ferences Regula értelmezéséről közölt forrásokat és tanulmányokat (VÁRNAI in VARGA \& VÁRNAI 2011, pp. 127-140). Az itt leírt gondolatok és hivatkozott források nagy részét annak köszönhetem, hogy 2003 2009 között definitor generálisként, a generális tanácsának tagjaként Rómában, a rendi központban, a Curia Generalizián éltem. Akkoriban kezdtem tájékozódni arról, hogyan is zajlott a Ferences Rend megújulása a II. Vatikáni Zsinat után. Sok érdekesség került a kezembe, ami azért is számított nekem újdonságnak, mert Magyarországon ennek a megújulásnak a folyamatából kimaradtunk, és anyagaiból kevés jutott el hozzánk. 2008 februárjában egy hetet töltöttem Paderbornban, abban a rendházban, ahol a Saxonia ${ }^{1}$ észak-német provincia levéltára is helyet kapott. A paderborni levéltárban egy különleges forrást mutatott nekem a levéltáros testvér, amit másolatban el is hozhattam: Lothar Hardick, a neves ferences kutató leveleit a római Curiából 1966-ból. Lehetne egy komolyabb dolgozatot is írni a Ferences Rend zsinati megújulásának folyamatáról, akár az egyes vidékek szerint, mivel azonban ehhez még további kutatásokra lenne szükség, úgy döntöttem, hogy lefordítom és közreadom P. Lothar leveleit. A jelen tanulmány igazából azt a bekezdést bontja ki, amely az említett tanulmányom 133. oldalán szerepel:

„A ferences reformkáptalanra egy nemzetközi 'megújulási bizottság' gyüjtötte össze a provinciákból a javaslatokat, és szerkesztette azokat egységes tervezetté.",

P. Lothar ennek a bizottságnak volt a tagja.

\footnotetext{
${ }^{1}$ Ebben az időben Németországban négy OFM ferences provincia müködik, közkeletű nevükön Saxonia (központja Werl), Colonia (Düsseldorf), Thüringia (Fulda) és Bavaria (München).
} 


\section{A levelek háttere}

\section{A szerző, Lothar Hardick}

A tizenöt levél címzettje Dietmar Westemeyer, a Saxonia provincia minisztere. Ő volt az, aki 1966 márciusában P. Lothart ajánlotta német részről a Commissio Centralis Renovationis, a rendi megújuláson dolgozó nemzetközi bizottság (bevett elnevezéssel „,aggiornamento-bizottság”²) tagjának. A bizottság 1966. április 12-től június 27-ig tartó első ülésszaka során feldolgozta az egész Rendből beérkezett javaslatokat, és az 1967-re tervezett nagykáptalan számára elkészítette az új Általános Konstitúciók első tervezetét. A levelek jelentősége ebből mindjárt kitünik: a Rend egyedülálló összefogása, közös gondolkodása áll előttünk, és kialakul néhány alapvető irányvétel is az új törvényhozáshoz - mindig tudva, hogy arról a döntés majd a nagykáptalan tagjait illeti meg.

Mi tette alkalmassá P. Lothart erre a feladatra? 1913. augusztus 24-én született, 1933. április 24-én öltötte magára a ferences habitust a Rendben, pappá szentelték 1940. január 7-én. A papszentelés után végigcsinálta a háborút mint szanitéc, hosszú ideig Itáliában volt, így megismerte a ferences történelem sok helyszínét. A háború után azonnal elkezdte az egyháztörténelem és a rendi történelem tanulmányozását, a 12. századi ciszter reformokról doktorált a münsteri egyetemen. Tanította a Rend és a provincia történelmét a Rend föiskoláján Dorstenben, müködése azonban nemsokára túllépett provinciája határain.

Három rendtársával együtt (Kajetan Esser, Engelbert Grau, Sophronius Clasen) 1951-ben elindította a Franziskanische Quellenschriften, a ferences források német fordításának sorozatát. Több szerzővel együtt Werkbuch zur Regel des heiligen Franziskus címmel 1955-ben kiadott egy regulamagyarázatot, amely méltán nevezhető mérföldkőnek a müfajban. ${ }^{3}$ Esserrel közös szerzőségben kiadta a Franziskanische Geistigkeit ferences lelkiségi sorozatot. 1961-ben P. Lothart a Rend generálisa meghívta, hogy a Firenze melletti Quaracchiban működő kutatóközpontban vezesse a történeti szekciót. 1962-1967 között a Franziskanische Studien, a német ferencesek negyedéves teológiai-lelkiségi folyóiratának szerkesztője. A hatvanas évek derekán tehát Hardick a német ferencesség lelkiségi megújulásának egyik legjelentősebb alakja.

P. Lothar sokat dolgozott ferences nővérek képzésében is, tanulmányi heteken (Werkwoche) ÉszakNémetországban, Ausztriában és Svájcban egyaránt, aminek egy harmadik könyvsorozat lett az eredménye: Wandlung in Treue (tkp. „Úgy fejlődni, hogy hüségesek maradunk”). Előadásai magnószalag formájában bejárták a német nyelvterületet, és nem csak a ferences nővérek között. Sok női ferences kongregáció köszönheti neki a zsinat utáni új konstitúcióit, és ennek tervei már a levelekben is megjelennek.

\section{A Rend zsinati megújulásának főbb eseményei német nyelvterületen}

1963 tavaszán tartotta soron következő nagykáptalanját a Ferences Rend, amelynek élén ekkor a francia Augustin Sépinski áll, aki a strasbourgi provincia tagja, 1938-tól miniszter provinciálisa. Ö 1945 ben került be a központi vezetésbe mint definitor generális, és az 1951-es nagykáptalanon választották meg először miniszter generálisnak. 1957-ben újraválasztották, mégpedig - az 1953-ban közreadott új Általános Konstitúciók ${ }^{4}$ szerint - 12 évre! Az 1963-as nagykáptalanon tehát csak definitorokat

Az aggiornamento az egyház zsinati megújulására vonatkozik, XXIII. János pápa szándéka szerint.

Ebből KAJETAN ESSER tanulmánya magyarul is olvasható: ESSER in VARGA \& VÁRNAI 2011, pp. 147-245.

4 Az Általános Konstitúciók (Constitutiones Generales) a Ferences Rend egészére vonatkozó, a Regulát a kor körülményeire alkalmazó szabályzata, amelynek módosítása a Szentszék engedélyéhez van kötve. 
választottak, generálist nem. A Rend összlétszáma ekkor 27.140 fö, ez a 20. századi legmagasabb érték: idáig növekszik, ettől kezdve csökken (tehát nem a zsinat után kezdett csökkenni...).

1963 júniusa: az első és második zsinati ülésszak között vagyunk. Az időszakot jellemzi egyrészt a szerzetesség általános megújulásának igénye, másrészt az utasítás a „kivárásra” a megújulással, hiszen még nem ismert, hogy mi lesz a zsinat útmutatása. A levelek bőséggel tanúskodnak arról, hogy a zsinat minta és eszmény a korszak ferencesei számára: át akarják venni módszereit, szakkifejezéseit, a megújulás lelkesedését. A legizgalmasabb átvétel a Gaudium et Spes lelkipásztori konstitúciónak megfelelő documentum spirituale terve volt (lásd VÁRNAI \& VARGA 2011, p. 132).

A német, holland és francia miniszter provinciálisok már a nagykáptalan idején megegyeztek arról, hogy 1965-ben tartanak egy „lelkipásztori kongresszust”, amelyen egyeztetik a megújulás elveit. Abban az évben, 1965. február 22-én Sépinski generális körlevelet ad ki a Konstitúciók megújításának tervéröl, és javaslatokat kér 1966. április 16-ig. Ez azért furcsa, mert a szerzetességről szóló zsinati határozat, a Perfectae Caritatis csak 1965. október 28-án születik meg, annak végrehajtási rendelete, az Ecclesiae Sanctae pedig 1966. augusztus 8-án lát napvilágot. A generális biztos lehetett abban, hogy szükség lesz a Konstitúciók megújítására, és elindította a konzultációt. Az erre beérkezett válaszokat már a nagykáptalan előkészítésének tartotta.

1965. április 20-24. között ülést tartanak Mönchengladbachban a német nyelvterület (a Germanische Zirkumskription) provinciálisai. A Saxonia provincia hírlevele szerint

„Kajetan Esser megtartotta híressé vált elöadását, amit már a Colonia gvardiáni
találkozóján is megtartott 1964. novemberében, és amit időközben
különlenyomatban kiadtunk." (Vita Seraphica 1965, p. 129)

A provinciálisok elhatározzák, hogy minden provinciában bizottságot hoznak létre az új szabályozás kidolgozására, és azt javasolják, hogy ezek neve legyen: „aggiornamento-bizottság”. A Rend szervezetében ebben az időben a nyelvi és földrajzi egységet képező területek ún. circumscriptio-t alkotnak, konzultatív testületként, az együttmüködés elősegítésére (ezeket ma konferenciáknak nevezzük). A provinciai bizottságok elnökei alkotják tehát a nyelvterület-szintủ bizottságot.

1965. augusztus 17-25. között a hollandiai Noordwijkerhout szemináriumának épületében kb. 150 ferences gyült össze a „germán” és francia nyelvterületröl, hogy a rendi lelkipásztorkodás alapkérdéseiről tárgyaljon. A kongresszus mindegyik napján egy vitaindító előadást hallgattak meg, majd tárgyaltak meg a résztvevők, akik között a központi rendi tanács három tagja is jelen volt. Kajetan Esser itt is megtartotta „híres előadását”, és egy résztvevő beszámolója szerint míg addig „lelkipásztori kongresszusnak” nevezték a gyülést, onnantól fogva „reformkongresszusnak”. Közös volt a meggyőződés, hogy kell a zsinati dokumentumok mintájára egy „lelki kiáltvány”, egy documentum spirituale, amely a ferences élet alapvető normáit megfogalmazza. Esser szerint ugyanis a regula nem csak, illetve nem elsősorban jogi célú dokumentum, hanem documentum spirituale. Ez azt jelenti, hogy az alapvetö lelki irányokat is megfogalmazza. Ezeket viszont minden korban újból ki kell mondani a megváltozott körülmények közepette. Sajnálatos módon föleg Itáliában Esser szóhasználatát reduktív értelemben fogták fel, mintha lekicsinyelné a regula jelentőségét (,„csak” egy lelki dokumentum), míg Esser egy mélyebb elkötelezettséget akart vele kifejezni. Enélkül a „kiáltvány” nélkül, úgy érezték, a zsinati megújulás kimerülne jogi paragrafusok módosításában. A documentum spirituale elkészítése Lothar Hardicknak is szívügye volt, ahogy arról a levelek tanúskodnak.

Érdekes, hogy Esser először rajta sem volt az előadók listáján. Az összes többi cím erős szociológiai irányulásról tanúskodik. Később tették be Essert, hogy legyen valami „spirituális” előadás is. Az ő

\footnotetext{
Lásd ESSER 1965.
}

6 Ezzel a sajátos szóval azt akarják kifejezni, hogy „,német nyelvü”, de azért nem egyszerüen „német”, hogy az osztrák, svájci és holland résztvevők ne érezzék alárendeltnek magukat. 
érdeme tehát, hogy a megújulásban a regula és a lelkiség szempontjai nagyobb szerepet kaptak. Noordwijkerhout később fogalommá vált a német, holland és francia nyelvterület ferencesei között: a zsinati megújulás lelkesedését idézte fel. Fél évszázad távlatából az ember azt kívánja, bárcsak jobban megszívlelték volna az itt képviselt, jóléti társadalomban élő provinciák J. F. Motte párizsi provinciális szavait:
„Ahol külsö megpróbáltatások nincsenek még, ott a szívek belsö elvilágiasodásának és ellanyhulásának képmutató veszélye odáig megy, hogy az ember kivánná, inkább látható veszedelmek legyenek, amelyekkel a harc könnyebben adódik."

\section{Az új Általános Konstitúciók elökészületei}

1965. október elején változás következik be a Rend vezetésében: Sépinskit kinevezik jeruzsálemi nunciussá. ${ }^{7}$ Hivatali ideje 1969-ben járt volna le. Nem túl merész a feltételezés, miszerint a kinevezés azt a pápai akaratot érvényesítette, hogy a Ferences Rend zsinati megújulását egy Sépinskinél nagyobb kaliberű és korszerübb szemléletű vezető vigye végig. Ez volt a német gyökerü brazil Konstantin Koser. ${ }^{8}$ 1965. november 3-án a Rend központi tanácsa a fennálló szabályok szerint őt „vikárius generálissá” választotta a következő káptalanig. Ekkor nem volt állandó „vikárius”, hanem a tanácstagok közül szükség esetén valakit megválasztottak vikáriusnak. Amikor tehát Hardick „p. vikárius generálisról” beszél, akkor valójában a Rend legfőbb elöljárójáról van szó. Kosert az 1967-es káptalan választja meg miniszter generálisnak, akit 1973-ban újraválasztottak, így 1979-ig, összesen 14 éven át vezette a Rendet.

A II. Vatikáni Zsinat utolsó ülésszaka tehát mozgalmas volt a Ferences Rend számára. Ebben az időben készül el a szerzetesi élet megújításáról szóló zsinati határozat, a Perfectae Caritatis is.

Konstantin Koser generális 1966. február 8-án körlevélben adja hírül, hogy különbizottságot kell létrehozni a Rend zsinati megújulásának előkészítésére. Március 15-én akarja felállítani a bizottságot, ezért kéri, hogy március 1-ig minden provincia küldjön be neveket szakterületek szerint: jog, rendtörténet, lelkiség, nevelés és tanügy, pasztorális, missziók, kormányzat. Így kerül képbe Lothar Hardick, aki azután kulcsszerepet játszik a bizottság munkájában, ahogy ez a levelekből is kiderül. 1966. március 19-én Koser kinevezi a bizottságot Commissio peritorum ad accomodatam renovationem Ordinis néven, melynek tagjai:

Evaristo Arns (Immaculata Conceptio provincia, Brazilia. Arns 1921-ben született, 1945-ben szentelték pappá, Párizsban doktorált klasszikus nyelvekből 1946-ban, 1950-ben pedig irodalomból. Később sao paulói segédpüspökké nevezik ki, majd 1973-ban bíboros lesz, elhunyt 2016-ban)

Pierdamiano Bertinato (Velence)

7 Sépinski naplójának tartalomjegyzéke megvan a strasbourgi ferences levéltárban. Eszerint 1965. szeptember 25én egy audiencián Cicognani bíboros közli vele VI. Pál pápa tervét, hogy jeruzsálemi apostoli delegátussá nevezik ki, másnap közli Cicognani bíborossal, hogy elfogadja, néhány feltétellel, szeptember 29-én ,tájékoztatja a definitóriumot a nagykáptalan elörehozásáról” (ez lehetett az egyik feltétel), majd bejegyzés szeptember 30-ról: „,mozgalmas definitóriumi ülés”. Sépinski a jeruzsálemi szolgálat után 1969. május 3-án uruguay-i nuncius lett, 1975-ben kora miatt lemondott, a Nápoly feletti La Palma konventbe vonult vissza, elhunyt 1978. december 31én. Naplóját a nápolyi ferenceseknél nem találtuk.

8 Született: Curitibae in Paraná, Brazília, 1918. május 9. Beöltözött 1934-ben, pappá szentelték 1941-ben. 19501953-ban Freiburgban doktorál, majd provinciájában tanít, felnőttképző kurzusokat szervez. 1956-1962-ben definitor és a rendi nevelés felelöse. Bár nincs nyoma az Acta Ordinis F. M. közlönyben, hogy zsinati peritus lett volna, tanúságok szerint betöltött ilyen szerepet brazil püspökök mellett. Az 1979-es nagykáptalan után visszatért Braziliába, tanított, lelkipásztorkodott, és több női szerzetesrendnek segített a káptalanjukon. Elhunyt 2000-ben. 


\section{Lothar Hardick (Saxonia)}

Urban Judge (Anglia)

Ambrosius Lubik (Lengyelország, Szilézia - akadályoztatás miatt távol)

Giacinto Marinangeli (Abruzzo)

Alan McCoy (az USA nyugati partján végig húzódó Santa Barbara provincia)

Juan Meseguer (Spanyolország, Cartagena provincia)

Ignacio Omaechevarria (Spanyolország, Baszkföld)

Luis Patiño (Kolumbia)

Pol de Léon Rolland (Lyon)

Rufin Šilić (Hercegovina)

Basilio Talatinian (Szentföld)

Beatus Theunissen (Flandria)

Sigismund Verhey (Hollandia)

1966. április 16-án kezd dolgozni Rómában a bizottság. Lothar Hardick hetenként próbál levelet írni Dietmar Westemeyer provinciálisnak, ez időnként késést szenved a sok teendő miatt. Érdekes körülmény, hogy a Curiával szemben bizalmatlanság volt a provinciákban, és azt feltételezték, hogy szigorú titoktartás mellett kell majd dolgozniuk. A Curia munkamódszerének az évszázadok során része lett a nyilvánosság bizonyos korlátozása, egyfajta önvédelemből, és még a Curia látogatása is korlátozva volt a testvérek számára. Koser azonban arra biztatta a bizottság tagjait, hogy tartsák a kapcsolatot provinciálisukkal. A leveleket a német nyelvterületen sokszorosítják és szétküldik, még a nővéreknek is, május 26. után pedig a holland ferencesek is megkapják.

E bevezető után lássuk tehát a leveleket.

\section{Levelek}

\section{1. levél}

Castel Sant'Elia, ${ }^{9}$ 1966. április $13 . / 18 .^{10}$

\section{Kedves Provinciális Atya!}

Szeretném tudatni Veled, hogy tehát tegnap pontosan megérkeztem Rómába. Életem első repülőútja máris nagy élmény volt, bár az élményt mindjárt eléggé lecsökkentette, hogy gyakorlatilag az egész úton erős felhőzet volt. Jól mondtad: nem telt el öt perc a felszállás után, és máris napsütésben voltunk. Csak röviddel a müncheni leszállás előtt lehetett megint látni a földet. Az Alpok fölött csak egy helyen tudtam mélyen lent megpillantani a havas csúcsokat. És aztán úgy saccolom talán Firenze után lehetett itt-ott megint látni a földet, persze a végén nagyon szépen a tengert. Úgyhogy: bár nem volt az élmény csúcsa, ami jó időnél elképzelhető, mégis nagyszerü volt. Alig szálltunk fel Düsseldorfban, máris ételt szolgáltak fel, nem egy nagy ebéd, de egész takaros. A Münchentől Rómáig tartó úton aztán megint felszolgáltak. Vagyis az ember, ha akar, akár Düsseldorftól Rómáig gyakorlatilag végig ehet.

9 A Saxonia provincia rendháza Rómától északra, amely néhány évtizedig szolgálta a német ferencesek pihenését és itáliai kapcsolattartását.

10 A dátumnál sokszor kézírással további napok szerepelnek. Ez azt jelöli, hogy P. Lothar nem tudta aznap befejezni a levelet, amikor elkezdte, hanem más napokon folytatta. 
P. Hugo ${ }^{11}$ jött értem a reptérre. Bementünk a generális Curiára. A ${ }^{12}$ Sigismund $\sqrt{ }$ generális definitor ${ }^{13}$ atyánál - mivel a $\mathrm{p}$. vikárius generális ${ }^{14}$ éppen nem volt ott - megpróbáltam szondázni a helyzetet, amennyire ilyen rövid idő alatt lehetséges volt. Íróasztalán három nagyon vékony dosszié hevert az egyes provinciákból beérkezett javaslatokkal, ezek körbejártak az egyes definitoroknál. Nem lehetett sok lap a dossziékban, max. 10. Valószínüleg nincs még egy circumscriptio, amelyik olyan gondosan elkészítette volna a dolgokat, mint mi. Na, de ezt majd még úgyis meglátjuk. P. Sigismund viszont azt mondta nekem, hogy minden beérkezett votumnál valójában eléggé egységes vonalak rajzolódnak ki. Teljesnek látszik az egység in puncto Fraternitas. ${ }^{15}$

Egy kicsit valahogy az volt a benyomásom a beszélgetés során, mintha Rómában - de talán ez a [P. Sigismund] személyes véleménye is - legszívesebben mielőbb egy kész jogi alkotást szeretnének látni, vagyis hogy talán fennáll a veszély, hogy elsietjük a dolgot.

Lent a portánál van a tárgyalótermünk, az asztalok már be voltak rendezve T-alakban. Ami még feltünt, hogy van egy újonnan felszerelt tévé- és filmszoba, új és kényelmes bútorokkal, még álló hamutartók is voltak. Láttam egy pingpongtermet is. Ez csak úgy apró jelek, amik azért valamit lehet hogy mondanak.

A generális definitor atyának az volt a véleménye, hogy a p. vikárius generális az első napokban majd részt vesz az üléseken, ami rendjén is van, mert tudnunk kell, mi az elképzelése a munkamódszerünkről és a pontosan körülírt munkafeladatról.

Fontosnak látom, hogy világosan felismerjük: ami most elkezdődik, az egy kezdet és nem egy sietős befejezés, ami után majd megint minden mély álomba merül.

Különben nem tudok még persze konkrétumokat mondani. Rendszeresen jelentkezem majd jelentésekkel stb.

Isten áldása legyen Rajtad és munkáidon!

szeretettel köszönt

(fr. Lothar)

Vinnen mindenki köszönt Téged! $\downarrow$

\section{2. levél}

Róma, 1966. április 16. / 21.

\section{Kedves Provinciális Atya!}

Ma reggel mi, a bizottság tagjai, koncelebrációban ünnepeltük a szentmiseáldozatot a p. vikárius generálissal. Külön erre az alkalomra új miseruhákat szereztek be.

Elkezdődött a munka. Majdnem az a kísértés van bennem, hogy az eddigieknek ilyen mottót adjak: „minden más, mint ahogy gondoltuk”. Következő van: a p. generális ma azzal az imával nyitotta meg az első ülést, amelyet a zsinaton a közgyülések előtt imádkoztak. Bevezetőjében ezt mondta: „Nektek kell megtalálnotok az utat, mert az még nem épült meg.” „Lehet, hogy a kimerülésig fogtok dolgozni.

11 Hugo Plassmann, a Saxonia provincia tagja, a Rend generális ökonómusa.

$12 \sqrt{ }=$ kézzel beszúrva.

13 Sigismund Strachwitz, a bécsi provincia tagja. Ezekben az években ő volt a német nyelvterületért felelős rendi tanácstag, így természetes, hogy P. Lothar nála kezdi a tájékozódást.

14 Konstantin Koser, akit Sépinski püspöki kinevezése után 1965. november 3-án választott meg a generális definitórium „vikárius generálissá”, a káptalanig szóló helyettessé.

15 Utalás arra, hogy a Rend identitásának lényeges eleme a testvéri közösség, és ezt jobban érvényre kell juttatni a Konstitúciókban. 
Viszont egy magasztos és szép feladatot bíztunk rátok.” (Nem egészen szó szerint, de nagyjából ezeket mondta, nem akarok hamisan idézni.)

A munkánk célkitüzései:

1) Összeszedni minden elemet, ami a provinciákból, egyénektől és a circumscriptiókból mint javaslat beérkezett. Ez lesz a munka kezdete. Úgy fogunk eljárni, hogy az egyes circumscriptiók képviselői a következő napokban összeülnek, hogy summáriumot készítsenek latinul, amiben minden lényeges elem röviden benne van.

2) Világosan meg kell fogalmazni az elveket, amelyek szerint egyes pontokat beveszünk, másokat nem. Ezzel tisztázódni fognak az 1) pontban összeszedett elemek.

3) Elaboratio schematis futurae legislationis (lehet, hogy több tervezet lesz). Ebben az összefüggésben egészen magától értetődően szó volt a directorium spiritualéról. ${ }^{16}$

Ami fontos: Az a szándéka, hogy senki elől semmit nem szabad elrejteni, hogy a generális Curiával szembeni bizalmatlanságnak véget vessünk. Expressis verbis megkértek minket, hogy a provinciálisainkat folyamatosan tájékoztassuk, és ha kell, megkérdezzük. Semmiféle titoktartási eskü tehát, hanem direkt felhívás, hogy közöljük a dolgokat. Tanácskozásainkon a határt csak a szeretet parancsa jelenti és a 8. parancs.

Amit itt kidolgozunk, azt elküldik a provinciálisoknak. Tölük a visszajelzéseket 1966. december 8ig várják. Akkor nekünk megint be kell ide vonulnunk, hogy elkészítsük a végleges szöveget.

A munkanyelv természetesen az olasz lesz. Hagyunk magunknak néhány nap időt, hogy jobban megismerjük egymást, és akkor választjuk majd meg az elnököt, alelnököt, titkárt és helyettesét. Jegyzökönyvet persze minden ülésen vezetnek, és az elnök mindennap bemutatja majd a p. vikárius generálisnak, aki kötött időben fogad. Amit a magunk körében „eldöntünk” mint proponendumot, annál mindig fel kell tüntetni a szavazatok számát stb. Kéthetenként tájékoztatást küldünk ki a munka folyásáról az egész Rendnek.

És az egészhez, amit a p. vikárius generális a munka módjáról és módszeréről mondott, ahhoz azt is elmondta, hogy az igazából csak egy javaslat az ő részéről, egy indíttatás, és teljesen ránk van bízva, milyen úton akarunk haladni, egyedül a rendszeres tájékoztatást kérte.

Talán érdemes ezeket a gyorsan leírt dolgokat megfelelö formában a testvérek tudomására hozni. Mert amilyen a helyzet itt, abszolút szükséges, hogy ellene dolgozzunk a legenda-képződésnek, miszerint (és ez többektől már írásban is befutott ide) a beküldött votumokat itt majd szépen iktatják, lefüzik, és aztán úgyis azt fogják csinálni, amit a generális Curia jónak lát. Tényleg nem így van, hanem a legnagyobb fokú nyitottságot nemcsak megtürik, hanem direkt kérik is. Talán nem fogunk tudni titeket úgy informálni, hogy az utolsó részlet is szerepeljen. Ez viszont nem az alapelveken fog múlni, hanem a munka nagy sokaságán.

Ahogy végignéztem a votumokat (fontos, hogy az ember ismerje a többi circumscriptiót is), újból és újból feltünt, mennyire teljes az egyetértés a lényeges dolgokban, mint az alapelveket, mind pedig az egyes kérdéseket illetően. Most éppen a kolumbiai provincia votuma van a kezemben, és meglepö, mennyire szinte szó szerinti egyezések vannak. Gondolok itt pl. a laikus testvérek helyzetére, aztán arra hogy „közösségi ima” legyen és ne „kórusima”. Van egy-két dolog, amiről azt hittük, hogy az csak a mi specialitásunk, de kiderült, hogy gyakorlatilag mindenki ugyanazokon a vonalakon mozog. Ez persze nem jelenti, hogy némelyik részletnél ne lenne majd kemény vita.

16 A bevezetőben említett „documentum spirituale”, olykor „directorium” néven szerepel. 
Az ellátásunk kitünő. A celláinkat nagyon jól felszerelték, még arra is figyeltek, hogy mindenhol legalább három szék vagy karosszék legyen a kisebb összejöveteleknek. És egyre csak kérdezik, hogy van-e valamire szükségünk.

Az én szobámba beköszön a Szent Péter kupolája. Ma van az emléknapja annak, hogy Ferenc fogadalmat tett a Pápának. Jó előjelnek tủnik tehát, hogy éppen ma kezdjük el a munkát.

Mára ennyit. Neked és minden testvérnek az egész provinciában szívből kívánom Isten áldását és nagyon sok örömet Rendünk új tavasza miatt, ami felé - ahogy remélem - haladunk.

szeretettel köszönt

fr. Lothar

\section{3. levél}

Róma, 1966. április 19. / 23.

Kedves Provinciális Atya!

A dolgok a következőképpen állnak: megegyeztünk, mekkorák lesznek a cédulák, amelyekkel a beérkezett anyagot rendszeresen és hiánytalanul meg akarjuk ragadni. Rögzítettük azt is, milyen felirata lesz ezeknek a céduláknak \négy színnel a nagy fejezetek $\sqrt{ }$. Ráírjuk mindegyikre az irat iktatószámát is, hogy az egészet a nagykáptalan használhassa mint dokumentációt. Az a célunk, hogy ellenőrizhető munkát végezzünk. Végül is csak megbízottai vagyunk az egyetemes Rendnek, bár azt fenntartjuk magunknak, hogy az objektíve bemutatott össz-rendi vélemény után a magunk votumát is hozzáfüzzük. Ezt el is várják tőlünk. Pontban 10.00-kor kell leszállítani a cédulákat. Kész van a tartalomjegyzék is az anyag áttekintéséhez, tegnap én készítettem el P. Evaristo Arnsszal és P. Ludovico Patiñóval. Ezután az lesz a feladat, hogy a meglévő anyagot átnézzük a szortírozás második lépésében. És ma délután lesznek majd az esedékes választások is. Nem sok jó néz ki szegény fejemnek. Mivel ugyanis nem jól venné ki magát, ha P. Evaristo Arns lenne az elnök, lévén hogy a p. vikárius generálissal egy provinciából való, úgy tünik, hogy a vélemények eléggé rám összpontosulnak. Örülnék, ha máshogy alakulna, de ha így kell lennie, késznek kell lenni rá.

Egy inkább magánjellegü info: Anélkül, hogy én szóba hoztam volna, a p. vikárius generális megpendítette a Taizé dolgát. ${ }^{17}$ Csak úgy mellékesen mondta nekem, hogy Taizében direkt többször is „szurkálta” öket, hogy jó értelemben nyugtalanságot keltsen. Az a véleménye ugyanis, hogy már maga a Rendben induló érlelődési folyamat megéri az egész vállalkozást. A Rendnek föl kell ébrednie, ez volt a szándéka, ezért akart Taizében néhány területet illetően sokkolni. Azt hiszem, jó, ha tudunk erről a koncepcióról, hogy egyes dolgokat jól értsünk. Mert hát az sem helyes, ha életünk vagy tevékenységünk bizonyos területeiről egyszerüen azt mondjuk: „Ott aztán biztos minden rendben van”, hanem most bátraknak kell lennünk és mindennek meg kell vizsgálnunk az érvényességét.

Ma van nálunk Werlben a laikus testvérek találkozója. A laikus testvérek kérdéséhez egy utalás: Kolumbiában a laikus testvérek taníttatására ezt a tervet állították össze:

81. akta, 31. oldal (megfontolások és javaslatok, 166.):

17 Nem tudjuk pontosan, mi is volt a szándéka K. Kosernek Taizével, csak annyi derül ki, hogy a Rend megújulásához pozitív inspirációt akart meríteni belöle. Thaddée Matura ferences, aki lelkiségi irodalmi mủveivel nagy hatással volt a Rendre, szoros kapcsolatot tartott fenn a taizéi közösséggel. 
„A laikus testvérek képzésének szakaszai: ${ }^{18}$

1. Elemi és - ha lehetséges - középszintű képzés, valamilyen formában (humán, müszaki, kereskedelmi, agrár stb.)

2. Egy év biblikus és teológiai bevezető

3. A noviciátusi év

4. Két év tanulás, ilyen témákkal: biblikum, teológia, pasztorális, pedagógia és pszichológia, gazdaság és adminisztráció, ferences lelkiség stb., választható kurzusokkal".

A venezuelai provincia pedig, ahogy P. Petro Damiani Bertinato elmondta, ezt a felépítést követi:

1. A fiataloknak van egy külön ház, ahol szakmát tanulnak. A városba mennek iskolába vagy mühelybe, ha még nem lenne szakmájuk. Emellett fut persze a vallási és jellembeli képzés, ami az életkornak megfelel. A szakmát lehetőleg ez alatt az időszak alatt szerezzék meg.

2. Jelöltség. Ha már van szakmájuk, a jelölteket a szakmájukban alkalmazzák. Ha még nincs, akkor a jelöltség alatt be kell fejezni. A jelöltek egy házban vannak a novíciusokkal.

3. Novíciátus. „Sajnos még a régi stílusban!”

4. Azután három évig egy házban vannak a fogadalmas testvérek. Itt még jobban specializálódnak, és elvégeznek minden munkát a közösségben. Csak nagyon ritkán ,adnak kölcsön” közülük valakit a provincia egy másik házába egy konkrétan rögzített munkára.

A testvérek sajátos munkái között említette: autómüszaki, elektrotechnikus, szakács, könyvelő, könyvtáros, katekéta missio canonicával stb. Itt jól figyelembe vették a müszaki és a modern követelményeket, mint pl. az autómüszaki és az elektrotechnika. A kolostorainkban mindkettőre egyre nagyobb szükség van.

Lehet, hogy ezek a szempontok érdekelhetnek. Sajnos nem tudtam elöbb elküldeni, hogy a laikus testvérek találkozójára odaérjen. Viszont mindkét helyen hangsúlyozzák, hogy ez csak egy első kísérlet. Mégis hasznos lehet, ha tudjuk, mások mit csinálnak, milyen irányban kísérleteznek. Esetleg valaki közülünk elutazik a venezuelai provinciába, hogy tanulmányozza a helyzetet. Azt persze tudni kell, hogy ők ott egyáltalán nem állítják, hogy feltalálták volna a bölcsek kövét, hanem csak bátran utakat keresnek.

Ha érdekel a - mostani! - életstílus, megírom: ebéd után a folyosón a generalátus előtt mindig összejön egy kis csoport. Ott az ablakpárkányon van egy nagy konzervdoboz, amelyben elhelyezhető a helyben elöállított szivar- és cigarettahamu. A p. vikárius generális mindig ott van. Ilyenkor néhány dolgot meg lehet beszélni. Így hát eltart sokszor du. 2-ig is, míg valaki elkezdheti a sziesztát. De du. 4 elött úgyse lehet senkivel beszélni a helyiek közül.

A vacsora 8-kor van. Utána lemegyünk a pincébe, ahol egy zsúrkocsin sütemények és bor van a rekreációra, ami állófogadás formájában zajlik, persze csak ha valaki nem megy át a szomszédba az újságos szobába, hogy ott az asztal körül megbeszélje a híreket, vagy a tévészobába, hogy olasz nyelvtudását a hírekkel fejlessze. 21.30-kor van egy csöngetés a rekreáció befejezésére. Reggel 5.30kor misézek, ha nincs koncelebráció 6.00-kor a konventmisén. Hetente háromszor van meghirdetve koncelebráció. Eddig csakugyan ez volt a ritmus, Vígy alakult ki: hétfőn, szerdán, pénteken. $\sqrt{ }$

Most ismét nekilátok a „Principia generalis legislationis futurae”-nek. Ha megvoltak a választások, megírom az eredményt.

Ez lett az eredmény: elnök: P. Beautus Theunissen $\sqrt{k i v a ́ l o ́ ~ n y e l v z s e n i ! ~} \sqrt{ }$, alelnök: P. Petrus Damiani Bertinato, titkár: P. Ludovicus Patiño, a titkár helyettese: P. Alanus McCoy, hírlevél-titkár: P. Ignatius Omaechevarria. Engem megkíméltek, mert azt mondták magukban, hogy a döntő kérdésekben mindig bevonnak, és ezért jó, ha nem vagyok lekötve más feladatban. Egyébként írunk majd a p. vikárius

18 Az eredeti szövegben az idézet spanyolul szerepel. 
generálisnak egy javaslatot, hogy vegyen még be a bizottságba egy négert meg egy japánt vagy vietnamit is.

Ezekből van, ami csak Neked szól, van, ami mindenkinek. El fogod tudni dönteni.

Isten áldjon Téged és az egész Provinciát!

szeretettel köszönt

fr. Lothar

\section{4. levél}

Róma, 1966. április 23. / 25.

Kedves Provinciális Atya!

Szombat délután és vasárnap szeretnénk magunkra is időt szentelni: fürödni, leveleket írni stb. Úgyhogy szombat délutánonként fogok Neked írni. Mivel csoportokban dolgozunk, a munkanapokon nem nagyon lehet hiányozni. Túl nagy dolgok nem történtek utolsó levelem óta. Az anyag legnagyobb részét analitikusan rávittük kartotékokra. Ehhez P. Patiño és én megterveztünk egy repertóriumot, amellyel 37 nagy témakörben az egész anyagot el lehet helyezni. A kétséges esetekre fenntartottunk két rubrikát: „varia” és ,investiganda”. Megeshet, hogy már magával a repertóriummal egy fontos előzetes döntés megszületett a Schema legislationis futurae tagolásához. Amellett voltam ugyanis, hogy a három fogadalom ne álljon az elején egyetlen blokk gyanánt, hanem próbáltam az egyes szakterületekhez rendelni ezeket, pl. az engedelmességet a fraternitas alá (ez teljesen a ferenci felfogás). Kell tárgyalni a fogadalmakat, nem kérdés, de szeretném ezeket jobban beépíteni az egészbe. Néhány hét, és látni fogjuk, mennyire sikerült ez. Elözetesen megegyeztünk P. Patinóval, hogy a következő napokban kidolgozzuk a $\mathrm{CCGG}^{19}$ szisztematikus új felépítését. Az ülés során jobban lehet tárgyalni, ha van valami konkrét előterjesztés, és ezzel egyes döntéseket bizonyos értelemben már előre el lehet kerülni. Még kell kb. két nap P. Sigismund Verhey-nek és nekem, hogy az egész anyagot analitikusan feldolgozzuk. A circumscriptiónkból beérkezett memorandumokban nagyon tartalmas mondatok vannak. Olykor akár négy különböző témakörben is külön kartotékra kell ezeket írni. Az elején ugyan nagyon szakszerü munkát igényel ez, de ezáltal egészen belejövünk minden gondolatba.

Ha az lesz a kérdés, hogy mindent megragadtunk-e az anyagból, akkor a szinopszisunk példásan elkészített II. kötete (Javaslatok a CCGG-hez) jól jön majd. Az a helyzet ugyanis, hogy a beérkezett javaslatok bizonyos területekre egyáltalán nem gondolnak, egyrészt azért, mert kevéssé érdekli őket, másrészt mert nem látnak szükségesnek változtatást (pl. a választások módja), ahhoz viszont figyelembe kell venni, hogy mindent minden oldalról megragadjunk.

Úgy tünik, a többiek is készen lesznek a munkájukkal úgy jövő szerdára vagy csütörtökre. Ekkor látunk neki a Principia generalia összeállításának, mindjárt azután pedig az anyag elbírálásának kritériumai jönnek. Van egy gondolatom - és P. Arns, P. Patiño és P. Verhey benne is volna - hogy az egész anyagot egy forgó rendszerben dolgoznánk fel. Vagyis: 5 háromfős csoport, mindegyik csoport egy rész anyagot dolgoz fel, sorban, ahogy a végleges tagolásból adódik. Az 1. csoport pl. tárgyalná a „De formatione fratrum minorum” témát: Principia generalis, 2. csoport: Opera vocationis stb. Ha az 1. csoport bemutatta a témáját, továbbmegy a 6. pontra stb. Így mindegyik csoportnak legalább 4 napja van a felkészülésre, és az egész ütemesen halad.

19 A Constitutiones Generales, az Általános Konstitúciók rövidítése. 
Ma megint elutazott Perantoni érsek. ${ }^{20}$ A szerzetesélet megújításáról szóló határozathoz készítendő instrukció bizottságában vett részt. Azt a felfogást követik, hogy nem lesz nagyon terjedelmes dokumentum. Viszont fontos dolgokat behoz majd. Állítólag a nagykáptalanok megkapják a jogot, hogy saját hatáskörben új statútumokat hagyjanak jóvá ad experimentum, úgyhogy ezeket nem kell először a kongregációnak benyújtani. Egyébként is meg akarják erősíteni a nagykáptalan törvényhozási jogkörét. A rendeknek azt sugallják, hogy ne akarjanak túl sok mindent mindjárt végleg rögzíteni, hanem nagy területeken hagyjanak nyitva vagy ad experimentum jelleggel. A rendek maguk lesznek hibásak, ha a kongregáció elé végleges jóváhagyásra benyújtott törvényhozási szövegekben túl sok mindent rögzítettek olyasmiből, ami még mozgásban van. Nekem úgy tünik, elég jó irányvonalak rajzolódnak itt ki. Végül is tényleg az a helyzet, hogy a CIC átdolgozását végző bizottság a rendekre vár, hogy hogyan látnak hozzá a munkához, hogy így legyenek modellértékủ esetek. Ez persze nem hivatalos hír, csak úgy adom tovább, ahogy a Rómában terjedő ,„pletykákat” szokták. Meg vagyok azonban győződve arról, hogy az irányelvek valóban így jelennek majd meg.

A p. vikárius generálisnak egész érdekes stílusa van, ahogy a dolgokat irányítja. Ha valamilyen szempontot be akar hozni a megbeszéléseinkre, akkor azt nem egy hivatalos intervenció formájában teszi, hanem egyszerüen bekopog valakihez a cellájába, és „privát” felveti a szempontot, amiről azt mondja, úgy tünik neki, hogy figyelembe kéne venni. Ennek során természetesen biztos abban, hogy a dolgokat befogadjuk. Úgy irányítja a dolgokat, amiről az olaszok azt mondják: „lavoro nel corridoio”folyosói megbeszélés ülés előtt. Az asztalnál P. Cairoli mellett ülök. Eddig a p. vikárius generálisról csak dicsérő szavakat hallottam tőle, és P. Cairoli eléggé nyílt ember. Abban persze nem vagyok biztos, hogy a p. vikárius generális stílusa mindenkinek tetszene a Rendben. El tudom képzelni, hogy van, aki nagyobb távolságra akarja tudni őt magától. A kérdés tehát az, hogy a testvériségnek mennyire kellene egy generális stílusát is jellemeznie. A személyi kérdést Nektek, minisztereknek kell eldöntenetek, én csak el akartam mondani, hogy a döntés még egyértelmübb legyen. ${ }^{21}$

Azt viszont e néhány nap alatt is egészen fontosnak találtam: több embert kell az ilyen nemzetközi központokba küldenünk tanulni, mint a $\mathrm{S}$. Antonio ${ }^{22}$ vagy akár Löwen. Talán úgy is lehetne, hogy bizonyos szakokat Németországban elvégez valaki, és ha doktorált, két félévre ide küldik. Túlságosan be vagyunk zárva a provinciáink kereteibe. Bizonyos dolgok árnyaltabban tűnnek fel, ha az egész Rend összefüggésébe vagy más nemzetekkel való élő kapcsolatban nézzük azokat. Ezt a kérdést nem szabad pusztán a stúdium felől eldönteni, hanem a kapcsolatok felől is, amiben egészen lényegesnek tartom a latin. ill. az olasz nyelv gyakorlását. Tudom, hogy mindegyik provinciának fáj, ha egy jóképességü embert meghívnak tanítani a S. Antonióra. Ha a jövőben ez így lesz, hogy szakértői csoportok, konzultatív csoportok stb. határozzák meg a Rend belső irányvonalát, amint az erős kívánságként jelen van, akkor nem kerülhetjük meg, hogy a mieinket is a központokba küldjük képzésre, hogy beleszólásunk lehessen.

Egyébként még mindig egész jól vagyok. Még soha nem voltam olyan rendházban, ahol ilyen gazdag választék lett volna az ételből. Legtöbbször persze ez nem téma köztünk, de mégis egy fontos szempont a munkához.

Holnap P. Sigismund és én el akarunk menni a kapucinusokhoz, hogy felvegyük az első személyes kapcsolatokat az ő aggiornamento-bizottságuk tagjaival. Az ilyen személyes kapcsolatok révén talán

20 Pacifico Perantoni a Rend generálisa volt. 1947. január 13-án XII. Piusz pápa közvetlenül nevezte őt ki elődje halála után, nem hívtak össze nagykáptalant a háború utáni körülmények miatt. Az 1951-es nagykáptalanon nem választották újra. 1952. január 31-én Gerace-Locri (Calabria) püspökévé nevezték ki, 1952. március 9-én szentelték fel. 1962-ban áthelyezték: lancianói érsek lett. A zsinaton a Coetus Internationalis Patrum tagja. 1974ben a pápa elfogadja lemondását, elhunyt 1982-ben.

21 A „döntés” a generális választása, amely a közelgő nagykáptalanon volt esedékes.

22 Ez az Antonianum, a Ferences Rend római teológiai fakultása. 
felsőbb szintü kapcsolat is elérhető. Arra gondolunk, hogy a CCGG végén lehetne egy szándéknyilatkozat a nagyon is támogatandó együttmüködésröl az OFMCap és az OFMConv ágakkal a nagy ferences család keretében.

Ennyit mára.

szeretettel köszönt

fr. Lothar

\section{5. levél}

Róma, 1966. április 30. / május 5.

[fejléces papíron: „Renovationis O. F. M. Commissio generalis” felirattal]

Kedves Provinciális Atya!

Névnapodra Isten gazdag áldását kívánom tiszta szívből. Holnap lesz itt a két Sigismund névnapja. A „kis” Sigismund - P. Sigismund Verhey - tegnap ágynak dőlt. Holnap már fölkel. Tegnap láza volt egy megfázástól, meg a gyomra is fájt. Mivel P. Marinangeli már az első héten influenzás lett, a házban fogalom lett a „febbre de la commissione”.

Nyilván szeretnéd tudni, hogy mi történt legutóbbi levelem óta. Teljes gőzzel nekiálltunk az egész anyag tagolásának. Mára (18.30) mindenki elkészült vele, kivéve a spanyolokat. Mivel P. Sigismund Verhey és én már tegnap délre elkészültünk a munkával, nekiláttam, hogy pontosan megnézzem, hogy a beérkezett javaslatok az eddigi CCGG melyik cikkelyeit érintik és melyeket nem. A teljes spanyol anyag ugyan még nincs a kezemben. A 655 cikkelyből viszont eddig csak 103 maradt érintetlenül, úgyhogy, ahogy mondják, kő kövön nem maradt.

Tegnap az ülésen egy további lépésről is döntöttünk: 5 albizottság dolgozza fel a beérkezett anyagot úgy, hogy ehhez megadják a gondolatokat, és megjelölik az érintett dokumentumokat. Ezzel az egész jóval tömörebb lesz. Egyes területeket ugyanis gyakorlatilag minden memorandumban ugyanúgy írnak le. Az anyagnak ezzel a szisztematikus megragadásával és bemutatásával már elkészül egy első tagolt feldolgozás, ezzel együtt pedig egy dokumentáció. Mindegyik pont tartalmazza ezeket: javaslat, indoklás, a votumok megadása az akta és az oldal számával. Mindezt egy kötetbe foglaljuk és megfelelő számban fénymásoljuk. Ennél gondoltunk az Exaten-bizottságra ${ }^{23}$ is, amely a directorium spirituale elkészítésén dolgozik. Nekik is megküldjük ezt a kötetet a kellő példányszámban. P. Sigismund Verhey, P. Ignatius Omaechevarria és én alkotunk egy albizottságot. A mi feldolgozandó témáink: 1. Javaslatok a bizottság munkamódszerére és a későbbi évek nagykáptalanjainak eljárásmódjára; 2. Alapvető irányvonalak az új törvényhozáshoz; 3. Regulánk teológiai magyarázata (directorium spirituale); 4. Testvériség: a testvérek szellemisége, állapota és jogai általában; 5. Minoritas, szegénység, munka. A többi albizottság témái: II.: Felvétel, nevelés, tanulmányok. III.: A ,jámborság kifejezései” mint a testvériség ügye vagy az apostolkodás. IV.: A Rend vezetése a generalátustól a házakig. V.: Missziók; a többi ferences család és rendi közösség; Egyház és világ; besorolatlan kérdések; még tanulmányozandó kérdések.

Ebből a beosztásból láthatod, hogy a mi albizottságunk kapta meg a döntő részt. Nálunk van ugyanis az általános alapelvek, valamint a testvériség és a minoritas döntő kérdésköre.

Amikor az ülésről kifelé fölvettem a rám eső kartotékok paksamétáját, azt mondtam az egyiküknek: „Mi aztán megkaptuk a legnagyobb és legnehezebb darabot.” Ö azt felelte: „Igen, ti a német

Ez a német nyelvterület provinciálisai által létrehozott bizottság, amelynek ülését 1966. augusztus 1-14. között Exatenbe tervezték, és amelyre P. Lothar maga is készült. Exaten Hollandiában, Limburg megyében, Baexem falu közelében egy kastély. 
nyelvterületen már annyit dolgoztatok ezeket a dolgokon, hogy más nem is nagyon került szóba." Nagyon is tudatában vagyok, mennyire nehéz kérdések ezek. De ha a Jóisten azt akarja, hogy valami rendes dolgot hozzunk ki belőle, akkor bizonyára segít is ebben. Ezt az ügyet nagyon ajánlani kell mások imádságába.

Ha az itt leírt lépés megvan - és gyorsabban fog menni, mint gondolnák - akkor jön a szöveg kialakítása, amely mint javaslat ismét kimegy megvitatásra egészen a legalsó szintig a provinciákba. Szeretnénk nagyon célzatos kérdéseket feltenni, hogy valóban kijöjjön az egész Rend véleménye. Hogy vajon akkor majd megszólalnak-e azok, akik nem küldtek be votumot, vagyis akik mindég csak siránkoznak? Megmutatkozott ugyanis, hogy ezek gyakorlatilag hallgattak, amikor arról volt szó, hogy valamit a Rendért tenni kéne. Helyenként szórakoztató olvasmány lesz a kötet, amit most majd összeállítunk. Milyen lenne például a javaslat, hogy egy generális vagy provinciális választása előtt legyen választási kampány? Kiválasztanak három jelöltet, mindegyik írjon egy „kormányprogramot”, és védje meg azt a káptalan elött. Aki a legjobban szerepel, azt választják meg. Emögött nyilván az a tény áll, hogy egy generális megválasztásakor aligha van olyan választó, aki mindegyik jelöltröl körültekintően tájékozódott, nem ismerjük eléggé egymást. Ez pedig egy olyan szempont, amit mindenképpen figyelembe kell venni. Talán eszünkbe jut még ehhez valami jó megoldás. Javaslatok azért vannak ehhez.

Nagyon érdekes ez a tény is: egyrészt nagyon sokat és komolyan beszélnek arról, hogy jobban kellene decentralizálni, több jogkört kellene tehát átadni a provinciáknak és a circumscriptióknak. Másrészt egész világosan látszik egy centralizáló tendencia is, amikor azt javasolják, hogy a generális számára a rendi élet minden területére nézve álljanak rendelkezésre igazi szakemberek, akiket bizonyos kérdések vizsgálatával megbízhat. Ez lényeges megerősítés lenne egy valóban lelki vezetéshez a legfelsőbb szinttől kezdve. A két tendenciát összehasonlítva látszik tehát, hogy nagyon is érzi mindenki, hogy a különbözőségben erősíteni kell az egységet. Egy Rendet akarunk és nem akarjuk azt szétverni. Számomra (és a bizottság sok más tagja számára is) egyre világosabb, hogy még mindig mennyire eleven a mi Rendünk, máskülönben nem kerülhetne sor egy ilyen intenzív közös munkára, aminek során persze a provinciák elég különbözöek.

Más: április 27-én este felhívott a főelöljáró nővér Salzkottenből, aki azért van itt, hogy felügyelje a generalátusuk építését. Ő maga akarta Neked elmondani az ügyét, de azon a szeptemberi héten, amikor a nővérközösségek elöljárói jönnek, ő már foglalt (káptalan Észak-Amerikában). Kérdezte, hogy megcserélhetjük-e a heteket. Nekem nincs kifogásom.

Kérdezted a leveledben, hogy mit adhatsz tovább a levelemböl. Ezt Rád bízom. Vannak benne dolgok, mint az iménti a nővérrel, ami másokat nem nagyon érdekel. Az alábbit azonban tényleg egészen privát csak Neked írom: P. Cairoli, aki mellett az asztalnál ülök, megsúgta, hogy őt fogják megbízni XXIII. János pápa boldoggáavatási ügyével. Egy idő múlva biztosan tudott lesz majd ez a Rendben, de egyelöre tartsd meg magadnak. Ez egy olyan nagy megtiszteltetés Rendünknek, hogy úgy gondoltam, névnapodon megörvendeztetlek vele! Szóban mondta meg neki a pápa, a hivatalos kinevezés még nem jött meg. Ha megjön, értesítést küldök a testvéreknek.

Továbbra is nagyon jól érezzük magunkat. Bár egyáltalán nem kívánkozok a Curiára, mégis el kell ismernem, hogy tényleg otthon érzem magam itt. És ezzel mindenki így van. Az elutazás napjára azért gondolunk örömmel, mert addigra az első része meglesz a munkának, és nem azért, mert nem szeretünk itt.

Mára ennyi. Sok apró részlet lenne még. De azt hiszem, a legfontosabbakat megírtam. szeretettel köszönt

fr. Lothar 


\section{6. levél}

Róma, 1966. május 10./ 13.

Kedves Provinciális Atya!

Ma kaptuk a hírt, hogy P. Evaristo Arnst segédpüspöknek nevezték ki Sao Paulóba. Holnap tehát már vissza is utazik Brazíliába. A bizottság munkájára nézve ez sajnálatos. Eddig ugyanis nagyban hozzájárult ahhoz, hogy a dolgok ütemesen haladtak elöre. Vajon behívnak valakit a helyére? Legfeljebb annyi értelme lenne, hogy a konzultációhoz lenne itt még egy peritus. Az egész munka felelősségteljes elvégzéséhez ugyanis az kellene, hogy egy olyan valaki végezze, aki velünk együtt csinálta végig az előző lépéseket is. Az ennek során nyert tapasztalatot és az anyag ismeretét más nem veheti át.

A dolgok így állnak: Elkezdtük pontról pontra kidolgozni annak összefoglalását, amit a testvérek beküldtek. Ez időnként igazi kereszt. Egyes dolgok ugyanis olyan általánosan vannak megfogalmazva, hogy csak tünődünk, mire is gondolhattak? Ha pl. azt vesszük, hogy a jellegzetesen ferences értékek között mik szerepelnek, akkor egy szép kis gyüjtemény jön össze a legeltérőbb dolgokból. Még olyanok is vannak, akik azt követelik, hogy Szent Ferenc Végrendeletét egészen újra kellene írni, mások az 1223 as regula kritikai kiadását szeretnék. Ezek csak a legszebbek! De azért ha az egészet nézzük, ez egy eléggé okos dolog, bár gyakran a következmények nincsenek végiggondolva. Ha tehát kidolgoztuk az összefoglalást, akkor ellátjuk egy jól célzott kérdéssorral. Minden bizottsági tag kap egyet az aktákból, és megírja véleményét vagy kiegészítését. Azután ezt összesítjük, és kidolgozzuk a második szövegtervezetet, amelyet az üléseken végigveszünk, és az egyes pontokról szavazunk. Így kialakul egy szöveg, amit átadunk a generális Curiának, és ők kiküldik a provinciákba.

Amit mi ezen az első ülészakon kidolgozunk, az még nem a javaslat az új általános konstitúciók szövegére. Inkább csak témakörök szerint mutatjuk be az anyagot. Ez megkönnyíti a feldolgozást a provinciákban. Ha most egy komplett szöveget hoznánk létre a konstitúciókhoz, az némelyek számára elég nehéz olvasmány lenne.

Amikor majd decemberben beérkeznek ide az állásfoglalások a provinciákból, akkor neki tudunk állni, hogy az egészet egy konstitúció-szöveggé formáljuk. Ami engem illet, nem érzem magamat képesnek arra, hogy az anyagot jogi nyelvezetben fogalmazzam meg. A jogi nyelvezetnek ugyanis részt kell kapnia ebben az egészben. Apránként azért egyre világosabban látunk. Ha minden jól megy, akkor június végére tényleg készen tudunk lenni ezzel az első szakasszal. A mi munkánk különösen nehéz, mert a legalapvetőbb kérdéseket a mi albizottságunknak kell feldolgoznia. A többi témakörben a dolgok lényegesen konkrétabbak. Három tervezet már kész, a hét végéig a maradék kettőt is elkészíti albizottságunk. Akkor a mi részünkre vonatkozóan rá tudunk térni a második szerkesztésre.

Érdemesnek tartom, hogy a német circumscriptio mihamarabb beadványt készítsen az új nagykáptalanról. Felfogásunk szerint ebbe az irányba kellene haladni: A nagykáptalant gondosabban kell előkészíteni, mint bármelyik eddigit. Az új irányvétel nekünk felajánlott lehetőségét ugyanis ki kell használni, de csak akkor lehet jól kihasználni, ha teljes felelősséggel és gondos előkészítéssel állunk neki. Kívánatos lenne ezért, hogy mielőbb alakuljon meg a nagykáptalan előkészítő bizottsága, amely mint szakértői csoport az egyes anyagokat feldolgozza. Ha ez egy capitulum extraordinarium, akkor a CCGG-ben eddig leírt eljárásmódtól feltétlenül el kell térni, mert annak alapján a szakcsoportokat csak a definitorium generalének azon az ülésén hozzák létre, amely a káptalan helyén a voltaképpeni nagykáptalant közvetlenül megelőzi. Az is kívánatos volna, hogy ne rögzítsék a káptalan időtartamát, hanem az elvégzendő munkát jelöljék meg végcélnak.

Talán hasznos, ha egyszerüen ideírom Neked, hogy a mi albizottságunk ehhez a ponthoz mit fogalmazott meg. Ez áll a „Propositiones de primo schemate provisorio” részben: „A káptalan ne csak a választásokra legyen, hanem az új törvényhozás előkészítésére is. Legyenek szakértői bizottságok, 
amelyek már a káptalan előtt meghatározzák a munkatervet. - Legyenek a káptalan utáni munkához is bizottságok, amelyek az év során négyszer tartanak ülést. A káptalanon háromféle ülés legyen: szakértői gyülés minden témához, nyelvek és circumscriptiók szerinti ülés, plenáris ülés. - Nevezzenek ki egy technikai bizottságot a káptalan előkészítésére. Legyen technikai vezetőség a káptalan megszervezésére (nyelvek szerint is). - Nevezzenek ki felelősöket a káptalani szertartásokhoz, föleg a liturgiákhoz stb. Legyenek felelösök a hírek közlésére a média felé."24

Ezt nem azért írom, hogy Ti is ezt írjátok, hanem hogy lássátok, milyen irányba megyünk, és a Ti részetekről támogassátok ezt az irányt. Mivel azt a részt mi, vagyis a mi albizottságunk dolgozza ki, sokban rajtunk múlik, hogy a commissio generalis mit fog javasolni. De jobb, ha ebben nem hivatkoztok ránk!

Egészségileg jól vagyok. Örömet okoz, hogy egy dologra koncentrálva neki lehet ülni valaminek. Csak az időjárás lenne egy kicsit jobb. Eléggé lehült ugyanis. Ma délután egy nagyon árnyékos részen 15 fok volt a hömérséklet.

Vasárnap kint voltam Castel Sant' Eliában. Nagyon csodálkoztam, hogy az emberek ott mennyire együtt ünnepeltek a liturgiában. P. Hugo, a gvardián, elég sokat elért ezen a téren. A p. prokurátor generális volt ott kb. 50 terciáriussal Rómából, és vele együtt koncelebráltunk, P. Sigismund Verhey és én. Hétfőn külön eljött hozzám, és egészen lelkesen beszélt a szép liturgiáról Castelben, és a terciáriusok is egész nap áradoztak róla.

Mára elég ennyi. Késő van, és kell az alvás. Remélem, hogy ezek azok az információk, amelyek Neked kellettek. Ha nem, akkor kérdezzél, és én válaszolni fogok, mert nem kellett hallgatási fogadalmat tennünk.

Isten áldjon, Téged és az egész Provinciát!

Egyébként: Pünkösd előtti szombaton az egész bizottsággal Assisibe megyünk, ahol az Angyalos Boldogasszonyban ünnepélyesen koncelebrálni fogunk vasárnap. Onnan Alvernára megyünk, ahol Pünkösd hétfốn a p. vikárius generálissal fogunk koncelebrálni. Azt hiszem, addig elég sok mindennel már megleszünk. Tehát,

szeretettel köszönt

fr. Lothar

\section{7. levél}

Róma, 1966. május 14. / 18.

Kedves Provinciális Atya!

A munkánk állásáról ezt lehet mondani: ma albizottságunk befejezte a munka első menetét. Elkészítettük az összegzést az összes, nekünk kiutalt pontról. Mivel az első három ponthoz már az összes többi bizottsági tag részéről beérkezett a véleményezés, és a negyedikről is a legtöbb már itt van, hétfőn albizottságunk elkezdi a második szerkesztést, amelynek során eldöntjük, hogy milyen utat válasszunk inkább. Nem tart már soká tehát, és megkapjátok az első szövegeket, hogy az egészet rendesen át lehessen ismét gondolni.

Időközben az olasz provinciálisok két atyát megneveztek a „Commissio Baexem”-hez ${ }^{25}$ a directorium spirituale kidolgozásához: P. Samuele Olivieri (Fiesole) és P. Efrem Bettoni (Milano). Mindkettőjüket személyesen ismerem. Nagyon örülök e kettő kinevezésének.

24 Az eredeti szövegben latinul van az idézet.

25 Lásd 23. lábjegyzet. 
Mielött P. Evaristo Arns elrepült volna, P. Sigismund Verhey közvetlenül feltette neki a kérdést, hogy mi a véleménye a p. vikárius generálisról. P. Evaristo kifejtette, hogy a p. vikárius generális valójában nem könnyen befolyásolható. A jó indokokra viszont nyitott, és olyankor meg tudja változtatni a véleményét, ha jó okokkal meggyőzik. Brazíliában viszont igazából progresszistának tartják, nagyon sok új dolgot elindított. Magától és másoktól is igen sokat vár el munka terén. Semmi esetre sem olyan, aki a véleményét hirtelen megváltoztatná, épp ellenkezőleg.

Ez a vélemény megegyezik azzal, amit egy brazil testvértől hallottunk az asztalnál a p. vikárius generális névnapjakor, amikor óvatosan érdeklődtem nála. Azt mondta, hogy a p. vikárius generális korábban sokkal sarkosabb volt a gondolataiban és terveiben, most viszont azt látja nála, hogy a nagy felelősség óvatosabbá és meggondoltabbá tette őt. Ezt egyszer szóvá is tette a p. vikárius generálisnak, aki ezt azzal magyarázta, hogy a Rend élén mégsem járhat el valaki olyan radikális és hirtelen módon. Mindenesetre ez nagyon jó jel, gondolom. Egy biztos: a p. vikárius generális sokkal intelligensebb, mint az elödje, gyorsabban és mélyebben átlátja a dolgokat, világosan lát minden összefüggést, és nem szüklátókörü. Ezt el akartam Neked mondani, bár szerintem P. Sigismund révén, aki biztosan megírja a provinciálisának, mindnyájan tudni fogjátok.

Jelenleg itt van Rómában P. Bertrand van Bilsen ${ }^{26}$. Május 19-én talákozunk vele. Van néhány dolog, amit át kellene gondolni, így pl. az, hogy a provinciák és a circumscriptiók szintjén az aggiornamentobizottságok hogyan dolgozzák fel a tőlünk kimenő anyagokat. Mi már gondolkodtunk azon, hogy hazautazásunk után hogyan tudnánk a provinciálisokat a legjobban és a leggyorsabban tájékoztatni. Az mindenesetre lehetetlen, hogy mindjárt a hazaérkezésünk napján legyen ez, mert ő még bizonytalan, és Nektek is megvannak a betervezett időpontjaitok. Talán július közepén lehetne időpontot nézni. Ha ugyanis ilyen ütemben haladunk, június végén már biztosan otthon leszünk.

Más egyelöre most nincs. Levélben nyilván nem lehet nagy elméleteket kifejteni, hogy hogyan vizsgáljuk és értékeljük az anyagot stb. Jól vagyunk. Kiválóan tudunk együtt dolgozni. Annyira be vagyunk fogva, hogy az otthoni helyzetre alig tudunk gondolni, egyszerüen nem jutunk hozzá.

Isten áldjon Téged és az egész Provinciát,

szeretettel köszönt

fr. Lothar

\section{8. levél}

Róma, 1966. május 18. / 23.

Kedves P. Dietmar Provinciális Atya!

Kedves P. Sigibald Provinciális Atya!

Április 30-án kiment a provinciákba a Commissio Centralis hírlevelének 1. száma. A 2. szám a napokban követi. Ezzel kapcsolatban az alábbiakat szeretnénk aláhúzni:

Fontos, hogy a Commissio Centralis közleményei lehetőleg minden testvérnek tudomására jussanak. A közlemények azonban ne csupán a provinciai lapokban jelenjenek meg, mert az nagy késést okozna. Arról van szó, hogy mihamarabb minden testvért tájékoztatni kellene. Így a házakban provinciai szinten már elő lehetne készíteni a Commissio Centralis első ülésszaka utáni munkamegbeszéléseket.

A hírlevél latinul készült. Ha tényleg el akarunk érni minden testvért, le kell fordítani. Ezért javasoljuk:

26 A holland provinciából. Ő volt a német circumscriptio titkára. 
A holland és flamand provinciákban a fordítás és a szétküldés feladatát átvállalja a német circumscriptio titkársága Brummenben.

A német és osztrák provinciák számára a fordítást és a szétküldést a werli provincialát vállalja át, mert P. Dietmar provinciális atya jelenleg a provinciálisi konferencia elnöke is. Szerintem elég lenne, ha ezeket a közleményeket egyszerüen lemásolnák és minden rendházba egyet elküldenének a circumscriptióban.

Mivel a rendi vezetésnek az a kívánsága, hogy az új törvényhozás anyagának most szétküldött tervezeteit a legalsó szintig mindenki megvitassa, ezért a megvitatás légkörét a hírlevelek fentebb leírt szétküldésével nagyon jól elő lehetne készíteni. Ha a Commissio Centralis az eddigiek szerint halad, a tervezetek rövidesen mind megérkeznek a provinciákba. Ezért sok múlik azon, hogy a hírlevelek közleményeit minél előbb mindenkinek továbbítsák. A hírlevél további számainak az a célja, hogy ösztönözze a megbeszélést, hogy a második ülésszakig remélhetőleg az egész Rendből beérkezzenek a vélemények. Eddig ugyanis csak egy meghatározott százalékuk reagált.

Mivel az ügy sürgős, feltételezzük a jóváhagyásotokat, és a kérdést a javasolt módon eldöntöttnek tekintjük.

szeretettel köszönt

/Bertrand van Bilsen /, a német circumscriptio titkára

/Sigismund Verhey, Lothar Hardick/, a Commissio Centralis tagjai

\section{9. levél}

Róma, 1966. május 18./ 22.

Kedves Provinciális Atya!

Nagyon köszönöm a május 14-i leveledet. Nem várom el, hogy mindig válaszolj. Azért írok ugyanis, hogy beszámoljak, és nem azért, mert postát szeretnék. Arról is van némi tudomásom, hogy mennyi munkád van.

Jó ötlet volt, hogy a híreket innen közvetlenül a provinciákba küldjük. Ez nagyon is megfelel annak, ami a Perfectae Caritatis határozat 4. pontjában áll mint követelmény: „A megújulás és a helyes alkalmazkodás csak akkor lesz eredményes, ha a szerzetesintézmény minden tagja részt vesz benne." Azt is hiszem, hogy a két ülésszak közti második munkamegbeszélések lényegesen intenzívebbek és érdekesebbek lesznek, mint a kérdőív kitöltése. Ide ugyan azért hívtak minket, hogy az új törvényhozást előkészítsük. Néha viszont úgy tủnik, egyáltalán nem az a lényeges cél, hogy az általános konstitúciók új kötetét nyomdába adjuk. Nem sokkal több-e, ha elérjük, hogy a Rend a maga minden egyes tagjában felelősséget érez önmaga iránt, érdeklődni kezd, és hogy a Rend a Rend számára ismét egy méltó beszédtéma lesz? Az egészet talán lehet egy érlelődési folyamathoz hasonlítani. És a p. vikárius generális is mondott ilyet egyszer, amikor azt mondta, hogy már csupán ezért az érlelődési folyamatért, amely most a szemünk láttára megindul, megérte az egész munka. Az érlelődési folyamatok olykor zavaros dolgokat is a felszínre hoznak. Ezt bele kell számítani. Nem szabad emiatt csalódottnak lenni.

Nálunk a munka napról napra több. Egyik albizottság a másik után elkészül az összesítésekkel. Amikor kiosztják, most már be se nyitnak az ajtón, csak az ajtó alatt becsúsztatják az aktát. A nap során gyakran jön ilyesmi az ajtó alatt a szobába. Minden akta feldolgozásához megvan a határidö. A mi albizottságunkban ma kezdjük el a második szerkesztést.

Az ideiglenes tervezetünk első három fő pontjánál megmutatkozott, hogy a témakörök állandóan átfedésben vannak. Ezért eldöntöttük, hogy a következő nagykáptalant, a regulamagyarázatot és az új általános konstitúciókat érintő kérdéseket a második szerkesztés során egyetlen aktában egyesítjük. 
Nagyon sok dolgunk volt a szegénység kérdéseivel: szentszéki tulajdonlás, apostoli szindikus, pénztilalom. ${ }^{27}$ Ennél rögtön az első összegzéshez már hosszabb kommentárokat adtunk, hogy elejét vegyük a vég nélküli vitáknak. Ha a megfelelö plenáris üléshez mindenkinek írásban kezében van az általunk kidolgozott gondolatmenet, akkor ezekben a nehéz témákban néhány dolgot mégis sikerült már előzőleg tisztázni. Hisszük azt is, hogy éppen ebben jó utat találtunk, amiből kiderül, hogy a Rendet továbbra is Szent Ferenc szellemének kell éltetnie. A szentszéki tulajdonlás kérdésében persze bele lehet kapaszkodni az asztalokba és székekbe a kolostorban, és feltenni a kérdést, hogy milyen értelme van a szentszéki tulajdonlásnak. Lehet viszont az egészen élesebben is nézni és meglátni benne a kérdést, hogy megvan-e bennünk a rendelkezésre állás készsége az egyházzal és a Szentszékkel szemben? Adott esetben talán még annak is volna értelme, hogy ezt a készséges rendelkezésre állást a Rend részéröl egy jogi jellegü nyilatkozatban ki is mondjuk. Nekem legalábbis úgy tünik, hogy az aggiornamento szellemének egy ilyen nyilatkozat jobban megfelelne, mint ha csupán eltörölnénk egy rendelkezést, amit szó szerint ma már úgysem lehet megtartani. Egy ilyen nyilatkozat végső soron egy nagyon konkrét életet jelentene Szent Ferenc szellemében.

Az ember itt ül és azon töri a fejét, hogyan találjuk meg a ma is érvényes modellt arra a lelkiségi vonalra, amely Ferenctől elér hozzánk? Valójában meg vagyunk győződve arról, hogy sok területen mégiscsak világosan lehet tudni dolgokat. Eközben persze szem elött kell tartanunk, hogy maga ez a lépés sem lesz tökéletes. Itt is szükség van a bátorságra, hogy vállaljuk a lelki szegénységet, amely komolyan veszi az emberséget, ami adott számunkra.

Megírtam már, hogy a bizottság a Pünkösd elötti szombaton a Porciunkula templomában, Pünkösd vasárnap pedig Alvernán a p. vikárius generálissal fogja koncelebrálni a szentmiseáldozatot? Olyan jó lenne egyszer direktben hallani, hogy Szent Ferenc Atyánk mit szól mindahhoz, ami a Rendben most kezdődik. De azt hiszem, a Jóisten másképpen is tudja irányítani a szíveket és elméket, mint hogy egy rendkívüli jelenés egész ünnepélyességét alkalmazza.

Ma itt volt P. Bertrand van Bilsen. Nagyon intenzíven átgondoltuk, hogy hazaérkezésünk után hogyan lenne a legjobb megtervezni a munkát? A cél ugyanis az, hogy lehetőleg mindenkit aktivizáljunk. Nem érezzük itt magunkat olyannak, akik mindent maguk akarnának csinálni, hanem csak a testvérek képviselőiként akarunk dolgozni. Ehhez viszont szükségünk van a testvérek véleményére. Kiszámítottam, hogy a kérdőíves akciónál múlt év végén a német provinciákban 26\%-os volt a részvétel. Ezzel szemben a braziliai Szent Kereszt provinciában $71 \%$ vett részt.

Mára befejezem. A levelet szakaszokban írtam, amint volt egy perc időm, és mindig ki kellett vennem a gépből. Remélhetőleg nem lett ettől zavaros a gondolat.

Teljesen egyezik a p. vikárius generális akaratával és kívánságával, hogy ilyen leveleket írjuk, ő ugyanis azt mondta, hogy ez ugyan többletmunka a számunkra, de nagyon fontos. A magunk számára fennmaradó rövid időket erre fordítjuk.

A testvérek egyébként tettek itt egy érdekes megállapítást, miszerint eddig még nem bukkant fel „spion” a generális Curián, aki azután fürkészett volna, hogy mi történik a bizottságban. Hasonló esetekben azelött mindig felbukkant egy „spion”. Most biztosan azért maradtak el, mert minden nyilvánosan folyik, és semmi titok nincs. Azért mégiscsak érdekes megállapítás úgy mellesleg.

szeretettel köszönt

fr. Lothar

\footnotetext{
${ }^{27} \mathrm{~A}$,szentszéki tulajdonlás” a ferences szegénységnek az a jogi vetülete, hogy a Rend minden tulajdona végső értelemben a Szentszéké. Az ,apostoli szindikus” a Rend életéhez és munkájához szükséges pénz kinevezett világi kezelöje. A „pénztilalom” az az elöírás, hogy a ferences nem érhet hozzá a pénzhez (amit különféle módokon kellett kijátszani a gyakorlati élet ésszerủ folytatásához).
} 


\section{0. levél}

Róma, 1966. május 18./ 22.

Kedves Provinciális Atya!

Azt írod május 14-i leveledben, hogy a Rómából küldött beszámolóimat szeretnéd elküldeni a Franziskanische Arbeitsgemeinschaft ${ }^{28}$ minden anyaházának. Nagyon is üdvözlöm az ötletet. Így ugyanis a testvéreink és nővéreink legalább némileg megtudják, mi is zajlik az I. rendben, és mik kezdődnek.

Szeretnénk Neked viszont még néhány gondolatot megírni, amit talán megfelelő formában el tudsz küldeni az anyaházaknak. Sokszor volt olyan benyomásunk, hogy az új általános konstitúciók kidolgozásával várni kellene addig, amíg nincs meg az új egyházi törvénykönyv. Itt Rómában viszont ez az elv: Az új egyházi törvénykönyvet kidolgozó bizottság arra vár, amit a rendek kidolgoznak, hogy legyenek modellek, amelyek szerint az egész egyházjog tájékozódni tud. A rendi közösségekre akarják hagyni, hogy új távlatok felé tegyenek próbálkozásokat. Nem úgy áll a dolog, hogy felülről erővel akarnának egy formát ránk erőltetni. Arról is beszélnek, hogy a megújulási nagykáptalanokat lehetőleg két éven belül mindenütt meg kellene tartani.

A nagykáptalanoknak tágabb jogköröket engednének, mint eddig. Így megkapnák a jogot, hogy új statútumokat maguk is bevezessenek ad experimentum. Nem kell hozzá a Szerzetesi kongregáció engedélye vagy jóváhagyása. Majd csak a végső megerőstést kell a Szerzetesi kongregációnak megadnia.

Át kellene gondolni azt is: itt azt tanácsolják, hogy az egyes szerzetesi közösségek új általános konstitúciója egy lehető legtágabb kerettörvény legyen, és hogy főleg azokat a dolgokat kell kihagyni vagy nem nagyon rögzíteni, amik még mozgásban vagy érlelődésben vannak. A szerzetesi kongregáció persze azt a statútumot fogja jóváhagyni az illető közösségnek, amit benyújtanak neki, még akkor is ha az illető közösség úgy gondolta, hogy mindent aprólékosan az eddigi módon rögzíteni kell. De az illető szerzetesi közösség ezzel saját magának ártana.

Vajon a ferences nővéreknek ebből a szempontból nem kellene-e nagyon is meggondolniuk, hogy az általános konstitúciókat úgy szerkesszék meg, hogy az többé-kevésbé minden németországi női ferences közösség alapszabályzata lehessen? Ha ugyanis azt javasolják, hogy lehetőleg általános szabályokat dolgozzanak ki, és a részleteket a szokáskönyvekre stb. hagyják, akkor mi marad mint valódi különbség az egyes közösségeknél? Alapjában véve nem igazán értelmes dolog, ha valaki két-három mondat megváltoztatásával egy általános kerettörvényben a „saját vonalát” akarná erőltetni. Ezt a javaslatot még nem abban az értelemben mondom, hogy ezáltal mindenki egyesüljön egy tényleges unióban. Azt gondolom viszont, hogy egyfajta föderációra lehetne törekedni, még ha nagyon laza értelemben is.

Lehet, hogy ezek a gondolatok némelyeknek szokatlannak és radikálisnak tünnek. Most van azonban itt az ideje, hogy van lehetöségünk valami újnak az elkezdésére. Emiatt szerettem volna mintegy könnyíteni a lekiismeretemen és ezeket leírni, hogy később ne érjen olyan vád, hogy a döntő pillanatban nem azt a tanácsot adtam, amiröl úgy gondoltam, hogy jó.

szeretettel köszönt

fr. Lothar

$\sqrt{ }$ Ebben a levélben megismételtem néhány, előzőleg is megírt gondolatot, hogy a levelet mint egészet fel tudd használni. $\sqrt{ }$

28 A ferences család szervezett együttműködése Németországban. 


\section{1. levél}

Róma, 1966. május 26. / 31.

Kedves Provinciális Atya!

A szent Pünkösd ünnepe alkalmából Neked és minden testvérnek szívből küldöm jókívánságaimat és üdvözletemet. Pünkösdkor Alvernán leszünk, és azt reméljük, hogy ezeken a szent helyeken valamit megtudunk Szent Ferenctől arról, amit nekünk ma itt tennünk kell. Időközben nagyon is szükségünk van erre a szünetre az assisi és alvernai kirándulással, mert a bizottságon már mutatkoznak a jelei annak, hogy a munka felöröl minket.

Ma reggel elkezdtük szövegében is megfogalmazni a cikkelyeket az új Általános Konstitúciókhoz. Nem könnyü, ha belegondolunk, hogy egyes dolgokat az általános felmentésekkel 750 éve hurcolunk magunkkal, ma viszont egy nagyobb tisztesség elve alapján másként kell fogalmazni. Éppen azon dolgozunk, hogy a pénz és a szentszéki tulajdonlás kérdésével mit kezdjünk. Néha az a benyomásom, hogy egyes dolgok jogilag úgy épültek ki, mint a sajttálon az üvegbúra, amely önmagában áll, egészen függetlenül és semlegesen azzal szemben, ami az életet, amely alatta van, ténylegesen betölti. Általában véve a Kisebb Testvérek voltak olyan okosak, hogy maguknak némileg kialakítsanak egy modus vivendit, de gyakran szenvednek attól az összeférhetetlenségtöl, ami abból adódik, hogy valamiröl kijelentjük, hogy a Rend sajátos szívügye, és rögtön felmentést is adunk magunknak alóla. Itt egy tisztességes megoldást kell találni. Úgyhogy itt állunk ezek előtt a problémák előtt, és faggatjuk a Jóistent, hogy miért akarta, hogy ezeket a dolgokat szabályozni kelljen. Persze mindig tudjuk azt is, hogy sok kontroll van, ami a munkánkat vizsgálja majd. Így lehet csak egyáltalán valamit elérni, ami tényleg elfogadható a Rend számára. Lehet, hogy a végén egy szót sem ismerünk fel abból, amit most kidolgozunk. Mégis reméljük, hogy lökést adunk a dolgoknak. Egy dolog a rekreáción minden következmény nélkül bölcs dolgokat bemondani mindenről, és ismét más dolog itt ülni és konkrétan megfogalmazni róluk valamit.

Tegnap itt volt P. Bosco, aki egy zenei konferencián van a kapucinusoknál. Adtam neki két képet a bizottságunkról. Ahhoz a képhez, amely kültérben készült és a Szent Péter kupolája látszik mögöttünk, ez a magyarázat:

Balról jobbra: 1. P. Rufinus Silić, 2. P. Hyacinthus Marinangeli, 3. P. Urban Judge, 4. P. Basilius Talatinian, 5. P. Pol de Léon Rolland, 6. P. Juan Meseguer, 7. P. Lothar Hardick, 11. P. Ignatius Omaechevarria, 12. P. Ludivicus Patiño, 13. P. Alanus McColy, 14. P. Sigismund Verhey, 15. P. Petrus Damiani Bertinato.

Talán gondol arra valamelyik sajtósunk, hogy ezt vagy más képet valahol felhasználjon.

Ahogy mondtam, a cikkelyek megfogalmazásán dolgozunk. Ennek az ülésszaknak a munkája ezzel a végéhez közeledik. Az anyagot egyelöre úgy hagyjuk, ahogy az egyes albizottságok eddig kidolgozták. Ennek során arra figyelünk, hogy semmi ne maradjon ki. Valószínüleg az ülésszak végén majd oda jut a dolog, hogy egy bizottságot megbíznak, hogy az egész anyagot egy új, szisztematikus rendbe rakja össze. Mivel ehhez az új rendhez a vázlatnak már megvan a koncepciója, ez a munka hamar megvan. Úgy lesz tehát valószínűleg, hogy ez a szerkesztő bizottság még néhány napot marad, hogy ezt elvégezze. Előfordulhat, hogy mindez rajtunk, az „A” albizottságon marad, mert mi dolgoztunk az alapkérdésekkel. Már látszik tehát lassanként a vége. Addig még persze nagyon sok munka van. Június 3-án az albizottságunk elkezdi bemutatni az általunk kidolgozott új cikkelyeket, a többi pedig majd ütemesen követi. Amit június 3-án az asztalra teszünk, az néhány lényeges döntést magával hoz majd. Nekünk kell ugyanis a szegénység, munka, testvériség stb. témák mellett a bevezető, magyarázó első fejezetet is elöterjeszteni.

Mára ennyit. 
szeretettel köszönt

fr. Lothar

\section{2. levél}

Róma, 1966. június 4. / 9.

Kedves Provinciális Atya!

Küszöbön áll az első ülésszak vége. Eddig az utolsó lépésig, ami a cikkelyek kidolgozása, a munkánk inkább az volt, hogy a provinciákból beküldött hozzászólásokat összefoglaltuk és kritikusan áttekintettük. Ehhez először is mindent kartotékokra írtunk. Ezeket a feljegyzéseket most egy testvér, aki nem tagja a bizottságnak, listaszerüen összeírja. Utána ezeket a Ferences Mária Misszionárius nővérek sokszorosítják majd. Ez egy dokumentáció, ahol megadjuk az akták számát és hogy milyen provinciából vagy nyelvterületről jött a hozzászólás. Ha valaki egyszer majd disszertációt akar írni Rendünk mai helyzetéről, akkor ebben a dokumentációban egy nagyszerü gyüjteményt talál. Úgy gondoljuk, hogy ez a dokumentáció azért ennyire fontos, hogy pontosan lehessen tudni, hogy ezt vagy azt a véleményt mennyire sokan vagy kevesen képviselik. Mindenesetre ezen a téren az egyes országok nem különböznek egymástól annyira, mint korábban gondoltam. Jóval több a hasonlóság a gondolkodásban, mint eddig hittük.

A p. prokurátor generális a napokban írásban kérdezte, hogy hány példányt kérünk. Egy példányt így is úgy is kap minden provincia. Mivel az ár 1 dollár, megfizethető a dolog. Úgy gondolom, legalább a tanulmányi házak kapjanak egy példányt.

Az összegzések, amelyeket ebből az anyagból készítettünk, és megjegyzésekkel elláttunk, ez volt a második lépésünk. Ezek az összegzések nem mennek ki a provinciákba, mert azt gondoltuk, sok lenne a jóból, mivel az előbb említett dokumentáció elegendő felvilágosítást ad. E két első lépés által már annyira beledolgoztuk magunkat az anyagba, hogy most már nem lesz olyan nehéz a harmadik lépés: a cikkelyek kidolgozása. Ezt úgy csináljuk, hogy nem csak egy megfogalmazás lesz, ha eltérő vélemények vannak. Adott esetben lehet akár három is. Így elősegítjük a megvitatást, hiszen gondolkodni kell rajta, ki melyiket részesítené előnyben.

Tegnap a mi „A” albizottságunk elkezdte bemutatni a cikkelyeket. Ragyogó volt. Nem úgy értem, hogy mindenki csak bólogatott rá, korántsem. Nagyon sok javítási ötletet kaptunk. Így még könnyebb lesz azt a változatot elkészíteni, amelyet kiküldünk a provinciáknak.

(Június 5-én írom tovább a levelet, nem nagyon van idő összefüggő írásra.)

Időközben az ülésen megvitattuk a „De formatione” tervezetet. Néhány testvér, pl. az angolok és amerikaiak június 15. előtt haza kell hogy menjenek provinciai káptalan stb. miatt. Úgyhogy addig minden pillanatot keményen kihasználunk. Érezni viszont, hogy négy óra ülésezés a legerősebb koncentráció mellett mennyire felörli az erőket, ha nap nap után csináljuk. Nem csak annyiból áll, hogy meghallgatjuk a bemutatást, hanem minden cikkelynél fontos előzetes döntések történnek. Most már délután is végig dolgozunk. Viszont most, hogy már látjuk a végét, könnyebb csinálni, mint ha a végét nem látva kínlódnánk.

Pünkösdkor Assisiben és Alvernán, Firenzében és Sienában voltunk. Alvernán Pünkösd elötti szombaton a vacsora után még tartottunk egy éjszakai ülést az éjjeli kórusig. Megtehettük, mert Pünkösd vasárnapján a koncelebráció csak 10.00-kor kezdődött. Firenzéből felküldték a klerikusokat az ének vezetésére. Mi pedig megengedtük ezeknek a klerikusoknak, hogy mint hallgatók ott legyenek az ülésen. Utána még sokáig vitáztunk velük. Itt Itáliában gyakran úgy gondolják, hogy Németországban, ill. az egész német circumscriptióban egy nagyszerủ ferences mozgalom zajlik, ezért sokat várnak el az északi 
ferencesektől. Sajnos az igazságot viszont tiszteletben kell tartani és leinteni az embereket, hogy amit egy maroknyi emberrel eddig csináltunk, azt ne tartsák általános mozgalomnak. Ha pl. az összes német provinciából csak $26 \%$ válaszolt a kérdöívre, világszinten a többi provinciából pedig $75 \%$, akkor az egy elég furcsa arány, akkor is, ha a német provinciákban kidolgozott és beküldött válaszok példamutatóan lettek elkészítve.

Jó volt, hogy itt volt időnk mint bizottság tényleg testvéri egységre jutni. Ahogy most a közös munka utolja kimeríti az idegek utolsó erőit is, egymásnak ugranánk, ha nem ismernénk már ilyen jól egymást. Most már tudjuk: még ha valaki hevesen tiltakozik is, az nem obstrukciós taktika, hanem a Rend egésze érdekében teszi. És gyakran tényleg kimondhatatlanul nehéz olyan formulát találni, ami valamennyire mindenkinek megfelel. Elég azoknak a testvéreknek a helyzetére gondolni, akik a vasfüggöny mögött élnek.

Lehet, hogy ez az utolsó előtti levelem az első ülésszakról. A következőt talán már odaadhatom, amikor hazaérek. Ahogy már írtam, a munka befejezése után néhány napra kimegyek Castel Sant' Eliába pihenni. Sok munka vár még ugyanis. Elég a documentum spirituale kidolgozására felállított bizottságra gondolnom. Az itt szerzett tapasztalatokat nagyon jól fogjuk tudni alkalmazni a documentum spirituale jó elkészítésében.

Egyébként, mi itt most egy teljesen más P. Marinangelit látunk, mint ahogy Te leírtad. Lehet hogy valami rosszat evett, amikor Te láttad. A kulisszák mögött akkoriban egy kemény pozícióharc folyt egyrészt ö, másrészt a p. generális és a p. stúdiumtitkár között. Valószínúleg annyira dühítette a dolog, hogy mindenfelé tört-zúzott. Itt ő nagyon kezelhető és nagyon kedves. Tényleg nem mondhatok mást. Ezt csak úgy mellesleg gondoltam megírni, mert a múltkor aggódtál.

Jó az Neked, ha írok a münsteri kolostorba, hogy jöjjenek értem a düsseldorfi reptérre? Vagy szeretnél velem rögtön beszélni? Úgy néz ki, talán június 23-én repülök haza. De még nincs eldöntve.

Mára ennyit.

szeretettel köszönt

fr. Lothar

\section{3. levél}

Róma, 1966. június 8. / 11.

\section{Kedves Provinciális Atya!}

Az első fogalmazásban eddig jóváhagytuk: Principia generalia, Caput praeliminare, De Minoritate, De Fraternitate, De Formatione et Educatione, De Regimine et Gubernio Ordinis. Vagyis jó nagy részével meg vagyunk, úgyhogy neki lehet állni a provinciákba kiküldendő szöveg elkészítésének. Csak akkor látunk viszont neki a szövegnek, ha már minden tervezetet bemutattak és megszavaztak. Mindig adódik ugyanis, hogy átfedések vannak az anyagban, amit figyelembe kell venni. Néha tényleg a kimerülésig csináljuk, ahogy a p. vikárius generális előre megmondta. Tegnap pl. 9.00-12.15 és 17.0020.10 tárgyaltuk az utolsó részét a rendkormányzat és vezetés tervezetének, míg végül megszavaztuk. A bizottság légköre kiváló. Ez éppen most bizonyosodik be, amikor nagyon gyakran előfordul, hogy egy cikkelyt vagy egy egész alfejezetet elvetünk. A mi albizottságunk még egész jól jött ki ebből, mert csak két cikkelyről kérték, hogy húzzuk ki. Némely dolgok „placet iuxta modum” mentek át. A modus javaslatait azonban írásban odaadták, úgyhogy a végső szerkesztés nem fog különösebb problémát jelenteni. Az egyik albizottsággal megtörtént, hogy az egész tervezetet a bemutatott formában gyakorlatilag elvetették. És ezt valóban csodálatra méltó módon elfogadták. A testvérek nekiültek, és éjfélig dolgoztak, hogy az egész tervezetet átfogalmazzák (inkább a kidolgozás módja volt a gond, nem 
az anyag), úgyhogy másnap már meg tudtuk tárgyalni az új tervezetet. Aznap, amikor bemutattam a mi albizottságunk tervezetét, utána azt álmodtam éjszaka, hogy az egész bizottság körülvett, mint egy arénában, és kórusban kiabálta, hogy „Placet, placet, placet”, az elnök pedig a ceruzájával kopogta hozzá az ütemet. Még álmunkban sem szabadulunk a munkától.

A napokban kaptam egy levelet egy dél-német generális elöljáró nővértől. Leiprecht rottenburgi püspök nagyon világosan megmondta a női elöljárók ülésén, hogy most az egész statútumot át kell dolgozni, és minden nővért be kell kapcsolni ebbe. Azt is mondta nekik, hogy semmi értelme, hogy mindegyik kongregáció külön babráljon a dolgokkal, hanem lelki irányzatonként össze kell ülni, és feltétlenül be kell vonni szakembert is. A női elöljárók egy része ettől nagyon megijedt, és most azt se tudják, mihez kezdjenek. Szerintem mi, az I. rend egy különleges helyzetben kapunk most hivatást. Kihasználhatjuk a lehetőséget, ami abban rejlik, hogy most tényleg egységes konstitúciókat lehet megcélozni minden női ferences közösségnek. Ami az észak-német területet illeti, már megvan erről a terv a közös munkahétre. Úgy tünik viszont, hogy tovább kellene menni, a dolog túlmegy a közös munkahét keretén. Mi lesz a dél-német, osztrák, svájci közösségekkel?

Az elöljárók június 20-22. között jönnek össze Vallendarban. Itt alkalom lenne, hogy a ferences provinciálisok erről elgondolkodjanak. Muszáj segítenünk a ferences nővéreknek. Egyedül nem tudják megcsinálni. És mivel a megújításban figyelmbe kell venni a propria indolest is, máshoz nem fordulhatnak a nővérek.

Mi a teendő? Mondanék erről néhány dolgot. Nem tudom, hogy a dél-német szerzetesek mennyire tervezték már meg az új konstitúciókat. Azt sem tudom, hogyan és mennyire sürgetően keresték meg a ferences nővérek az érintett provinciálisokat. Talán még mindig a sokk hatása alatt vannak. Fel kell oldanunk a félelmeiket és segítenünk kell nekik. Én magam kész vagyok átadni az itt szerzett tapasztalatokat, a dél-németeknek is. De erre csak akkor vagyok kész, hogy ezt egységesen tudom megadni minden generális és provinciális elöljáró nővérnek, másként nem megy. Úgy képzelném el, hogy a nővérek elkezdenének egy kérdőíves akciót, ha még nem tették. Ezeket a kérdőíveket egy csoport nővérnek kellene kiértékelnie, egy I. rendi szakértő vezetésével. Át lehetne venni a munkamódszert, amelyet a mi bizottságunk itt kidolgzott és most használ. Egyrészt tehát segítenünk kellene, de nem mindent egyedül csinálni, hanem be kell vonni a nővéreket.

A provinciálisoktól viszont kérem, hogy ezt az én ajánlkozásomat ne úgy fogják föl, hogy mindenáron magamhoz akarok ragadni mindent. Annyi az egész, hogy tudatában vagyok a saját helyzetemnek: az írásaim és a magnószalagok révén a ferences nővérek között van egy bizonyos tekintélyem, és az itteni munka miatt pedig van jócskán tapasztalatom az eljárásmódot illetően.

Vagyis: mielőbb össze kellene hívni egy capitulum generalissimumot az érintett ferences nővérek számára. Ki hívja ezt össze? A legfőbb elöljáró nővéreknek el kellene mondani a teendőket. Hol lehetne ezt megrendezni? Az I. rendtől ki legyen a vezetője? Nem szeretném egyedül csinálni. Nem lehet ugyanis tudni, hogy ilyen-olyan dolog miatt nem esik-e ki az ember. Az is nagyon jó lenne, ha az I. rendektől lenne egy egységes képviselet.

Amíg erről meg nem egyeztetek Vallendarban, ne hagyjátok abba az ülést! Nem olyan könnyü összehívni egy ilyen provinciálisi találkozót. Ne várjatok arra, hogy a sokk alatt álló ferences nővérek egyenként kopogtatnak nálatok, hogy jöjjön valaki segíteni nekik. Érezniük kell részünkröl a biztonságot, és a felajánlott segítséget szívesen veszik majd. És azt nagyon világosan mondjátok meg a ferences nővéreknek: a szakértőinket, akiknek amúgy éppen elég dolguk van, nem tudjuk szétforgácsolni, hogy minden közösségnek egyenként külön segítsenek. Ha az I. rend és a szabályozott III. rend együttmüködése Németországban már most példa sokak számára, akkor ebben a helyzetben is példa lehetünk. 
Sajnos a VDO ${ }^{29}$ ülése előtt már nem érek vissza, itt a munka úgy néz ki elnyúlik június 24-ig. Addig nem lehet elmenni, amíg mindent el nem intézett az ember. Másnak nem lehet átadni. Úgyhogy legkorábban június 25-én érkezem, de lehet, hogy csak június 26-án.

Mára ennyit!

szeretettel köszönt

fr. Lothar

\section{4. levél}

Róma, 1966. június 14. / 18.

\section{Kedves Provinciális Atya!}

Ahogy már írtam az egyik előző levélben, P. Cairoli szívesen elküldi P. Antonellit Dortmundba, hogy a Jordan testvér ügyét előbbrevigye. ${ }^{30}$ Lehet, hogy nem fejeztem ki magamat elég világosan a múltkor. Mindenesetre jó lenne, hogy P. Cairolit hivatalosan levélben kérnéd, hogy küldje el P. Antonellit, ahogy felajánlotta. P. Cairolinak ugyanis, lévén némi tapasztalata ezen a téren, azon az állásponton van, hogy kifejezett kérés vagy utasítás nélkül senkit nem küldhet ki egy provinciába ilyen munkára. Vagyis írjál hamar, hogy a dolog ne halasztódjon.

Mivel az angol P. Urban Judge-nak június 11-én haza kellett utaznia, mert mint kusztos részt kell, hogy vegyen a provinciai káptalanon, június 10-én megtartottuk az utolsó ülést, amelyen a bizottságnak minden tagja részt vett. Tehát csak abban az értelemben volt utolsó, hogy mindenki ott volt. A munka továbbmegy. Ezen a június 10-i ülésen a p. vikárius generális is jelen volt. Felköszöntöttük öt a papi jubileuma alkalmából. Tartott nekünk egy beszédet, amit tartalmilag így tudnék visszaadni:

A bizottság elnöke megkapta a felhatalmazást, hogy a bizottság azon tagjainak engedélyezze a hazautazást, akikre a végső munkálatoknál nincs már szükség. A p. vikárius generális megköszönte a bizottságnak az elvégzett munkát, és gratulált ahhoz, hogy ez az óriási munka ilyen gördülékenyen haladt. A levelekből, amelyeket a jubileuma alkalmával most kap, nagyon érezhető, hogy lényegesen több készség van most a tényleges megújulásra, mint az elején. Ezért gyümölcsözőnek kell mondanunk az utat, amit a Rend ezen a téren választott. Az elején sokkal több negatív reakcióra számítottak, féltek attól, hogy mindent el akarnak majd törölni, és nem számoltak ennyi konstruktív javaslattal. Amikor pedig a provinciák szintjén elkezdték a munkát, mégiscsak születtek nagyon pozitív és aránylag érett írások is. Megmutatkozott, hogy a Rend tényleg valóra akarja váltani azt, amit Ferenc akart, bár a formáknak ma másoknak kell lenniük, mint annak idején. Terméketlen vállalkozás lenne, ha a Rendre valamit felülről akarnánk ráeröltetni. Ezért volt annyira szerencsés dolog, hogy az impulzusok elég erősen jöttek alulról, a bázisról. Ahogy a dolgok alakultak, az is kiderült, hogy akik azelőtt a generális Curia ellenfelei voltak, most a Curia munkatársai lettek.

Az is nagyon szerencsés rendelkezés volt, hogy semmilyen titoktartásra nem köteleztek minket. Mindeddig semmilyen oldalról nem érezhetö, hogy sötét pletykák vagy fantáziáló képzelgések kaptak volna lábra. Senki nem jött mint „spion” Rómába, hogy hátulról kíváncsian kikémlelje, mi készül. Mindez régebben menetrendszerü volt, amikor döntő tárgyalások folytak. Most mindez elmaradt, mert minden nyíltan történt. Így az alkalmas megújulás impulzusa csakugyan lelki megújulás lehetett a Rend számára. Mindannyiunknak kötelessége, hogy ezt az impulzust továbbra is elevenen tartsuk. Van még ugyanis olyan része a Rendnek, amelynek még meg kell térnie a valódi megújuláshoz. Ha a Rendünk

29 Verein der Deutsche Ordensoberen - A német (férfi) szerzeteselöljárók egyesülete (tkp. konferenciája).

30 A generális Curián Cairoli volt a posztulátor generális, mellette Francesco Antonelli mint munkatárs dolgozott. Jordan Mai dortmundi ferences testvér (1866-1922) boldoggáavatása ma is folyamatban van. 
kész valóra váltani, ami le van írva az egyes dokumentumokban, akkor a jövőben kétségtelenül új virágzásnak indul majd.

Egy éve még senki sem hitte volna, hogy a következő káptalanig össze tudjuk hozni az új Általános Konstitúció szövegét. Ma viszont ez már világosan elvárható. A provinciákban elvégzett előmunkálatok lehetővé tették, hogy a bizottság már ki tudta dolgozni az új Általános Konstitúciók tervezetét. Nem fogunk habozni, és a következő nagykáptalanon a Rendnek megadjuk azt a nyugalmat, amelyre szüksége van. 1969-ben azután tarthatunk egy nagykáptalant, amelyen ki lehet értékelni a megtett utat.

Abba az illúzióba viszont nem szabad magunkat beleringatnunk, hogy az új konstitúciók majd kőbe vésettek lesznek és sokáig nem változnak. Van ugyan egy mondás, miszerint a törvények megváltoztatása a rossz kormányzás jele. Ma viszont ez már nem érvényes. Azt a fejlődést nézve, amelyre a mai világ gondolkodása ráállt, egy dolog régi volta értéket jelent, de inkább muzeális értéket, mint az élet számára való értéket. Ez a felfogás pedig a lelkiségre is hat. A munka, amit a bizottság tagjai ezekben a hónapokban végeztek, maguk a tagok számára is személyes nyereséget jelent. Többet tudnak, mint azelőtt, tapasztalatot szereztek, és közelebbi kapcsolatba kerültek a Rend valóságával. A bizottság tagjai ne bánjanak fukarul ezzel a nyereséggel, és ne akarják maguknak megtartani, hanem azon igyekezzenek, hogy minél több emberrel megosszák.

A p. vikárius generális az egész Rend nevében köszönetet mondott, és így folytatta: „December 8án viszontlátjátok egymást a munka második részének elvégzésére. Akkor majd látni fogjátok a munkátok kritikáját is." Amíg ugyanis a provinciákban megvitatják a kiküldött anyagot, Rómában is át fogja nézni néhány bizottság azt: egy dogmatikai bizottság, egy exegetikai, egy történeti és egy kánonjogi bizottság. Az ülést Szent Ferenc utódjának áldásával zártuk.

Elöre láthatólag június 18-án megyek Castel Sant'Eliába. Ki akarom pihenni magam. Június 27-én először Münchenbe repülök. Oda értem jönnek autóval Augsburgból, ahol a dél-német ferences nővérek néhány föelöljárója együtt lesz (Kloster Maria Stern, Sterngasse). Kb. június 29-én megyek majd vonattal haza. Az ember már érzi a kemény munka következményeit. Mindenhová velem jön a munka. Eltart éjjel 1-ig, mire elalszom. Reggel pedig 5-kor ismét kezdődik a nap. Akárhogy is vagyok: nem vagyok elégedett azzal, amit megcsináltunk. Nagyon érzem a magam munkájának korlátozottságát.

Nos, kedves P. Provinciális, ennyit mára. Ha visszatekintek arra, amit itt elvégeztünk, és összehasonlítom a leveleket, amiket írtam, tudatában vagyok, hogy tényleg magunknak kellett megkeresnünk az utat. Még meg is változtattuk a célkitüzést. Először ugyanis csak arról volt szó, hogy a beküldött anyagot feldolgozzuk és a provinciáknak állásfoglalásra megküldjük. Mégis örülök, hogy rászántuk magunkat a tervezet kidolgozására az új Általános Konstitúciókhoz. A konventuálisok és a kapucinusok megfelelő bizottságai úgy gondolják, hogy mi választottuk a jobbik utat, amikor nem az eddigi szövegből indultunk ki, hanem egyszerüen új útra merészkedtünk.

Isten áldása legyen Veled!

szeretettel köszönt

fr. Lothar

\section{5. levél}

Róma, 1966. június 18. / 21. / 22.

Kedves Provinciális Atya! 
22.00 óra van. Vacsoránál a p. vikárius generális elköszönt tőlünk, P. Sigismundtól és tőlem, és minden jót kívánt a „lavori intersessionali”-hoz. ${ }^{31}$ Amikor a többiektöl elköszönt, ezt az utolsó mondatot nem tette hozzá. Biztosan a mi circumscriptiónkban különösen jól müködő munkára gondolt. Holnap P. Friedhelm értünk jön (P. Sigismund és én) Castel Sant'Eliába. Június 27-ig maradok Castelben. Bár kiderült, hogy több generális elöljárónő nem tud eljönni Augsburgba, mégis szeretnék úgy utazni, hogy a müncheni reptérről az Augsburger Sternfrauen nővérek hozzanak el. Egyrészt így rögtön megtudom, mit mondott a rottenburgi püspök a nővéreknek Untermarchtalban, másrészt egy kicsit be tudom vezetni a kérdésbe az új generális elöljárónőt. A Sternfrauen nővérek július végén tartanak nagykáptalant. Június 29-én vonaton utazok majd Münsterbe. Remélem elnézed, hogy a hazautazással nem sietek annyira, bár így nem érlek el Téged, mielőtt a gyógyfürdőbe utazol. Egyszerủen szükségem van most néhány nap teljes nyugalomra.

Kérdezed, hogy mikor kellene megtartanunk a provinciálisok találkozóját Saalmünsterben. P. Sigismund és én egyetértettünk abban, hogy a legjobb lenne július 12-én kezdeni. Esetleg jó lenne, ha még július 12-én vagy vacsora elött, vagy rögtön utána egy első bevezetést adhatnánk. Így még a július 14. egész nap megvan, és július 15-én ebédig dolgozhatnánk. Mivel az aggiornamento-bizottság július 15-én jön Saalmünsterbe, és még meg kell csinálni nekik a szobákat, az volna jó, ha július 15-én délután utaznátok el, hogy átadjátok nekik a helyet, ha esetleg nem lenne elég szoba mindkét csoportnak.

Légy szíves, hagyd meg nekem a címedet Bad Schwalbachban. Szeretnék ugyanis mindjárt küldeni Neked egy példányt az új CCGG-böl. Úgy intéztük, hogy 30 példányt egyszerü módszerrel rögtön lehúztunk, hogy a generális definitórium azonnal foglalkozni tudjon az anyaggal. Közben valami jobb eljárással elő lehet állítani a példányokat, amelyeket a provinciákba kiküldünk. Tehát Neked az első 30ból küldenék egyet.

Leveledből úgy tűnik, nincs elképzelésed arról, mi megy ki innen a provinciákba. Ezek lesznek:

1) Epitome propositionum Provinciarum. Ez az összegzése annak, amit az egyes kérdésekhez a provinciákból és a circumscriptiókból beküldtek, megjelölve a hozzászólások forrását. Ezt úgy neveztük el, hogy opella, bár meglesz vagy 300 oldal. Kb. 12 napon belül elkezdik küldeni. Ebből az Epitoméból - alias opella - Te 10 példányt rendeltél. Ezt nem szántuk lefordításra. Ez az eredménye a kb. 5000 kartotéklapnak, amelyből a mi „A” albizottságunknak pontosan 1400 lapot kellett feldolgoznia.

2) Schema pro CC. GG. Ezt kell lefordítani. Nagyon röviden: 269 cikkely lett, a régiben 655 volt, tehát 386 cikkellyel kevesebb most. A koncepció azonban egészen más, alig vettünk át cikkelyt. Magunk is érezzük, mennyire ideiglenes ez az első tervezet. Túl kevés volt az idő, hogy jobban finomítsuk. De talán jó is így, mert így a vitákat jobban ösztönzi.

3) Criteria in schemate constuende adhibita. Ez kb. 15 oldal. Ez egy olyan dokumentum, amelyben teológiailag meg akarjuk indokolni a munkamódszerünket. Ezt is le kellene fordítani. Ezt a fordítást én magam megcsinálom, talán már Castel Sant'Eliában elkészülök vele. Asztali olvasmánynak is ajánlható, mert jó bevezetést nyújt.

4) Summarium ex schedis circa documentum quoddam spirituale. Bár csak augusztusban ül össze Exatenben a bizottság, amelyet erre a documentum spiritualéra létrehoztak, mégis jó, ha a dolognak nincs olyan színezete, hogy itt az északiak akarnak valamit a Rendre ráerőltetni. Ebbe is fontos az egész Rendet bevonni. Egy kísérölevélben ezért mindenkit kérünk, hogy tegyen javaslatokat. Ugyanakkor világossá tettük, hogy nem általános tanácsok kellenek, hanem csak már megfogalmazott szövegek. Ezzel szerintem biztosítható, hogy egyrészt a Rend ne érezze magát lerohanva, másrészt viszont túl sok anyag se érkezzen.

$31 \mathrm{Az}$,ülésszakok közötti munka” eredetileg a zsinati ülésszakok közötti időben végzett bizottsági munkára vonatkozott. Újabb példa a zsinat szakkifejezések átvételére. 
Egyébként június végéig még nem jön ki az instrukció a Perfectae Caritatis határozathoz és a többi zsinati dokumentumhoz. A Szentatya határozatlan időre meghosszabbította a vacatio legist. Ez azzal függ össze, hogy a kúriát át kell szervezni, és az instrukciókban ezt már figyelembe akarják venni. Ezért egyes munkák még a levegöben lógnak. Ez különösen a minoritákat érinti, akik június 14-én kezdték meg a nagykáptalanjukat itt Rómában. A minoriták miniszter generálisa mondta nekem a mi vikárius generálisunk jubileumán, hogy nem is annyira a római hőségtől szenved, hanem a vacatio legis kitolásától és az instrukció egyre későbbi megjelenésétől. Talán a szeptemberi munkahetünkre is még ez az átmeneti jelleg nyomja rá a bélyegét.

Eljött tehát az első ülésszak vége. Nagyon kellett sietnünk a munkával. Hiszem azonban, hogy amit létrehoztunk, az mégiscsak egy elismerésre méltó teljesítmény, minden hiányosságával együtt, amit mi magunk látunk a legjobban. A második ülésszakon mindenképpen nyugodtabb munkára van szükség, bár akkor már nem lesz olyan sürgős. Akkor ugyanis a provinciák beküldött anyagai alapján kell kiérlelnünk az egészet. Elrepült az idő.

A hadseregben most így mondanák: „Meldekopf Rom stellt den Funkbetrieb ein.”32

Isten áldása legyen Veled. A magam részéről azt tanácsolnám Neked: ne vigyél magaddal semmi munkát Bad Schwalbachba! Próbálj egy ideig nem csinálni semmit! Nem tudom, képes vagy-e még rá. Magamról annyit mondhatok, hogy ez nekem se megy könnyen, de jövő héten Castel Sant'Eliában megpróbálom. Vigyél magaddal jó könyveket, olvass el reggel nyugodtan egy fejezetet, jegyzetelés nélkül, és hagyd, hogy a nap során a fejedben járjon. Egyes dolgok kiérlelődnek, ha egy ideig valódi nyugalomban gondoljuk át azokat.

Tehát: Viszontlátásra!

szeretettel köszönt

fr. Lothar

\section{A bizottság munkájától a nagykáptalanig}

\section{Az Exatenben tartott tanácskozás}

A levelekben említés történik az „Exateni Bizottságról”, vagyis egy konferenciáról, amelyet a hollandiai Exatenben terveztek tartani külön a documentum spirituale kérdéséről 1966. augusztus elején. ${ }^{33}$ A paderborni levéltárban 1966. július 16-i dátummal olvashatók Westemeyer provinciális levelei, amelyben résztvevőket kér az exateni konferenciára: Recife (Brazília), Chicago (USA), San Sebastián (Spanyolország) provinciáiból. Fennmaradt tovább 1966. július végéról Westemeyer levele, amelynek végén megköszöni Konstantin Koser rendfőnöknek, hogy jön Exatenbe. Az ülésre kiosztott témák:

1. A zsinati egyháztan, az egyház megnyílása a mai pluralista világra

2. A szerzetesség mai felfogása: helyük az egyházban, a propria indoles

3. A Rend kötődése az evangéliumhoz, forma sancti evangelii, mai biblikus tudomány szempontjai

4. A deklerikalizáció

5. Az egyetemes Rend, missziók, világvallások

6. A mai életérzés: a „horizontalizmus”, a mai fiatalok

7. Gyakorlati kérdések: pénzhasználat szabályozása 
1966. augusztus 1-14. között Exatenben tehát a német nyelvterület különbizottsága, meghívott vendégekkel kibővítve, dolgozik a documentum spiritualén. Lothar Hardick írja egy levelében, hogy az egész Rendben megvan az igény documentum spiritualéra, de nem világos, hogyan is nézzen ki. A német nyelvterületen erről kialakult gondolatok a Rend többi részében néhol újnak és idegennek tünnek. A 2. ülésszakon (1966. december) feltétlenül el kell majd dönteni, hogy a documentum spirituale külön álljon az Általános Konstitúcióktól, vagy hozzákapcsolják a törvényekhez? Koser rendfőnök végül valóban részt vett az ülésen. Egy beszámoló szerint ,tájékoztatót tartott a nagykáptalanról, közölte a dátumot (május 4.), valamint két döntést: lesz szimultán tolmácsolás, és a választások elött lesznek tanulmányi napok a káptalan tagjai számára”.

\section{Az Ecclesiae Sanctae motu proprio}

VI. Pál pápa 1966. augusztus 6-án adta ki Ecclesiae Sanctae címmel azt a motu proprio dokumentumot, amely a Perfectae Caritatis és három másik zsinati határozat (Christus Dominus, Prespyterorum Ordinis, Ad Gentes) végrehajtási utasítása. Ebben többek között az alábbi fontos rendelkezéseket hozza:

a. A szerzetesrendek zsinati szellemü megújulását maguk a rendek tervezzék meg és vigyék véghez egy káptalanon, amelyet 3 éven belül meg kell tartaniuk, minél szélesebb körü konzultációval előkészítve.

b. A megújulásban nemcsak a Perfectae Caritatis dokumentumra, hanem a zsinat teljes anyagára kell támaszkodni.

c. Minden rend hozzon létre új konstitúciókat (a regulát aktualizáló alapszabályokat), és ezekben ne csak jogi normákat hozzon, hanem fejtse ki a szerzetesi élet szentírási és teológiai alapjait és az Alapító szándékát is, a rend egészséges hagyományával együtt.

Ez utóbbi rendelkezés az előkészítő munkát abba az irányba terelte, hogy a documentum spirituale ne külön irat legyen, hanem része legyen az új konstitúciónak, hiszen célja éppen az lett volna, amit a motu proprio is megfogalmazott.

Mindezek fényében a Rend vezetése most már konkrét tervekkel készülhetett a megújulási káptalanra. 1966. szeptember 7-én Konstantin Koser rendfönök levelet ír a testvéreknek a nagykáptalan előkészítéséről. A színhely a Porciunkula lesz. A bizottságokat nem tudják előre összeállítani, mert némelyik provinciában a káptalan nem sokkal a nagykáptalan előtt lesz. A nagykáptalan egyik fő szerve a Commissio Centralis Renovationis lesz. Öt bevezető előadás is lesz: 1) Mit tanít a történelem a reformokról? 2) Realizmus, és nem utópia a megújulásban. 3) A ferences szerzetesi érzék és a megújulás. 4) Az egyházi érzék és a megújulás. 5) A lelkipásztori érzék és a megújulás. Lehetőség lesz más nyelvek használatára, az adott nyelvterületnek kell hoznia két tolmácsot.

\section{A bizottság második ülésszaka}

A készület a Rend legtöbb területén az első tervezet megvitatásával folyt. A terveknek megfelelően 1966. december 8. kezdettel megtartotta második ülésszakát az aggiornamento-bizottság. P. Lothar ezen részt vett, de a munkáról nem maradtak fenn az első ülésszakhoz hasonló levelek, csak egy összegző jelentés, amelyet a bizottság küldött szét a Rendben.

Az első ülésszakon részt vett bizottsági tagokból a másodikon is ott volt: Pierdamiano Bertinato, Alan McCoy, Lothar Hardick, Juan Meseguer, Ignacio Omaechevarria, Luis Patiño (elnök), Pol de Léon Rolland, Rufin Šilić, Basilio Talatinian, Beatus Theunissen, Sigismund Verhey. Új tag lett a vietnami P. An, azután Stepahno Bianchi (a közben provinciálissá választott Giacinto Marinangeli helyett), Pedro Rosales (Kolumbia, Evaristo Arns helyett), január 23. után pedig Ignatius Kelly (a vikáriussá választott 
Urban Judge helyett). Részt vett a lengyel Ambrosius Lubik is, aki az első ülés idején akadályoztatva volt.

A munka alapelve ismét az volt, hogy a definitórium nem ad utasításokat, csak tájékoztatást vár el, továbbá hogy a tagok feladata a Rend minden részéből érkezett vélemények összegzése, és nem a sajátjuk érvényesítése. Így láttak hozzá a mintegy 2500 oldalnyi terjedelmü 159 beadvány feldolgozásának, és 1967. február 6-án végeztek azzal. Ekkor Koser generális levélben tudatja a provinciákkal, hogy elkészült az Általános Konstitúciók nagykáptalani tervezete, és kiküldik.

A kutatásnak innentől fogva az 1967-es nagykáptalan aktáit kell vizsgálnia.

\section{Utószó}

Végezetül néhány szóban méltatnunk kell a P. Lothar leveleiből megismert munkát a Rend zsinati megújulásán. Szembetűnő a zsinat munkájával való lelkes azonosulás, a rendi megújulási folyamatok összhangba helyezése a zsinat eredményeivel. A Rend talán legkiválóbb felkészültségü tagjai végezték ezt az intenzív és magas színvonalú intellektuális munkát, számítógép nélkül, latinul, olaszul és más nyelveken.

Amikor Lothar Hardick és Sigismund Verhey az ülés után beszámol a német nyelvű provinciálisoknak, és ők már a Rend jövőjét kezdik tervezgetni, a két páter , lehüti a kedélyeket azzal, hogy a circumscriptiók másutt nem úgy müködnek, mint a német területen”. Kétségtelen tehát ennek a területnek a szervezettsége, de ez az egész Rendre nem volt jellemzö. Ahogy bepillantást nyerünk a német nyelvterületen folyó megújulási erőfeszítésekbe, egy gazdag ferences hagyomány működését látjuk, amely sok gyümölcsöt termett az egész Rend számára, de amelyet sajnos ma már a puszta létében fenyeget a komoly létszámhiány.

Fél évszázad távlatából persze sok kérdés is megfogalmazódik. Vajon nem bízott-e a vezetés túlságosan abban, hogy a Rend megújulása bekövetkezhet az értelmi belátás, az intellektuális továbbképzés révén? Eléggé megszívlelte-e a Rend Koser generális többszöri figyelmeztetését, hogy a megújulásban az új dokumentumok létrehozása csupán egy részfeladat, a forrás a belső, lelki elkötelezettség megújítása? Tanuljunk történelmünkből.

\section{Irodalom - References}

BIEGER, D. (2005): Das Ringen um ein erneuertes Verständnis der Franziskusregel auf der Tagung in Exaten (1966). Ein Beitrag zur Erforschung der nachkonziliaren Ordensreform im Franziskanerorden. Wissenschaft und Weisheit, 68(2): 267-289.

ESSER, K. (1965): Die endgültige Regel der minderen Brüder im Lichte der neuesten Forschung, Coelde, Werl (Westf.).

ESSER, K. (2011): „Melius catholice observemus” - Rendünk regulájának magyarázata Szent Ferenc írásainak és egyéb szavainak fényében. In: VARGA K. \& VÁRNAI J. (szerk.) (2011): A ferences regula. Korai és mai értelmezések. Vita Consecrata 5., L’Harmattan - Sapientia Szerzetesi Hittudományi Főiskola, Budapest, pp. 147-245.

VARGA, K. \& VÁRNAIJ. (szerk.) (2011): A ferences regula. Korai és mai értelmezések. Vita Consecrata 5., L'Harmattan - Sapientia Szerzetesi Hittudományi Főiskola, Budapest.

VÁRNAI, J. (2011): A Regula a 20. században. In: VARGA K. \& VÁRNAI J. (szerk.) (2011): A ferences regula. Korai és mai értelmezések. Vita Consecrata 5., L’Harmattan - Sapientia Szerzetesi Hittudományi Főiskola, Budapest, pp. 127-140.

VITA SERAPHICA (1965), Saxonia provincia hírlevele. 